Portland State University

PDXScholar

8-6-1996

\title{
Thermal Preference of Spring and Fall Chinook Salmon (Oncorhynchus tshawytscha) during Smoltification
}

Sally T. Sauter

Portland State University

Follow this and additional works at: https://pdxscholar.library.pdx.edu/open_access_etds

Part of the Biology Commons

Let us know how access to this document benefits you.

Recommended Citation

Sauter, Sally T., "Thermal Preference of Spring and Fall Chinook Salmon (Oncorhynchus tshawytscha) during Smoltification" (1996). Dissertations and Theses. Paper 5252.

https://doi.org/10.15760/etd.7125

This Thesis is brought to you for free and open access. It has been accepted for inclusion in Dissertations and Theses by an authorized administrator of PDXScholar. Please contact us if we can make this document more accessible: pdxscholar@pdx.edu. 
The abstract and thesis of Sally T. Sauter for the Master of Science in Biology were presented August 6, 1996, and accepted by the thesis committee and the department.

COMMITTEE APPROVALS :

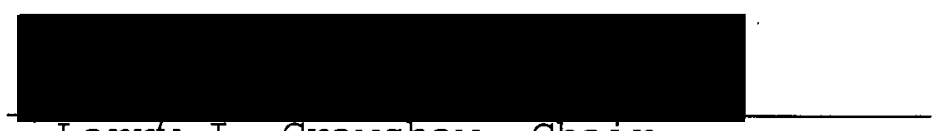

Larry I. Crawshaw, Chair
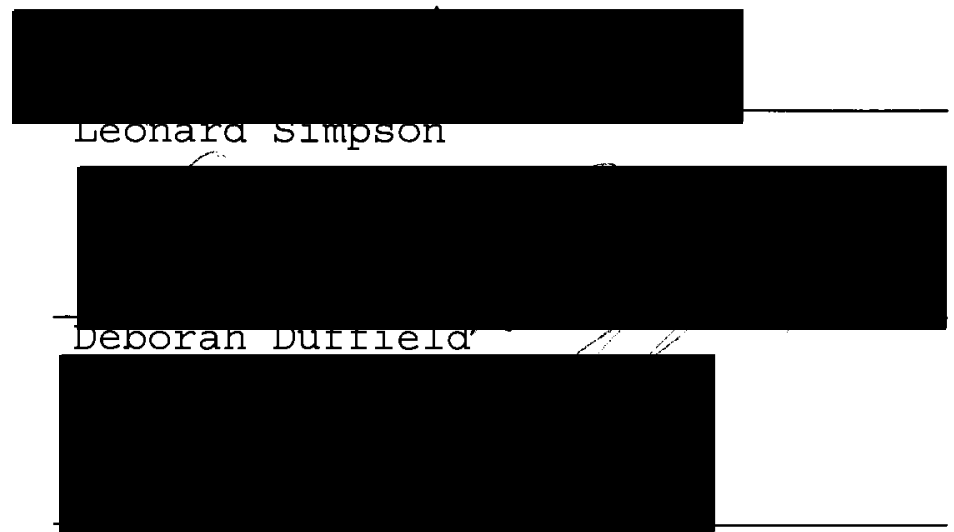

Alec G. Maule

DEPARTMENT APPROVAL:

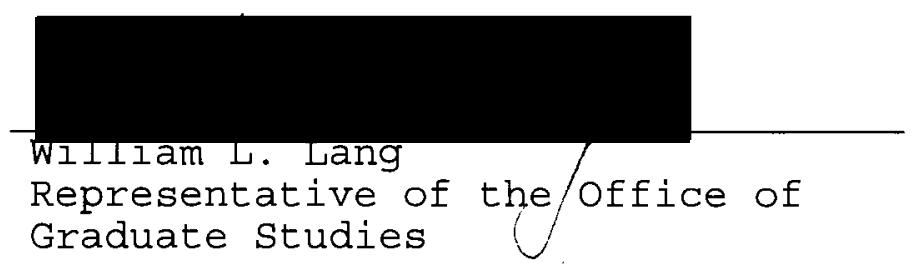
Graduate studies $U$.

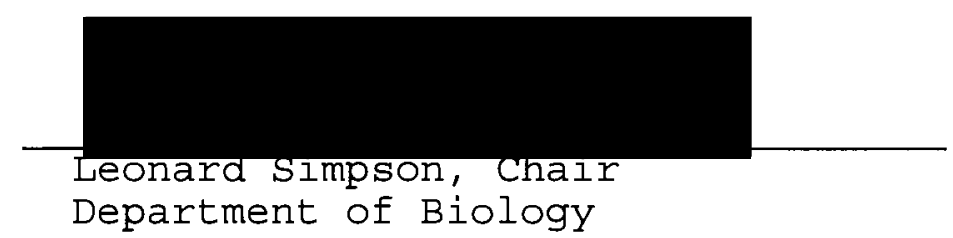

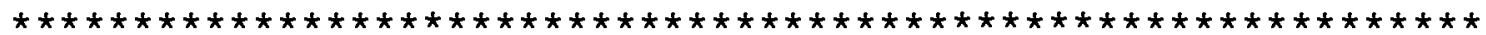
ACCEPTED FOR PORTLAND STATE UNIVERSITY BY THE LIBRARY by on 9 lakex 1996 


\section{ABSTRACT}

An abstract of the thesis of sally $T$. Sauter for the Master of Science in Biology presented August 6, 1996.

Title: Thermal Preference of spring and Fall Chinook salmon (Oncorhynchus tshawytscha) during smoltification.

Innate species-specific temperature preferences of $\mathrm{fish}$ are subjected to fluctuations under a variety of environmental, physiological, and developmental conditions. The temperature preference patterns of two ecologically distinct races of chinook salmon (Oncorhynchus tshawytscha) were investigated as laboratory held animals underwent smoltification. Smoltification is a distinct developmental stage in the life history of anadromous salmonids when juvenile fish undergo profound behavioral, morphological, and physiological differentiation prepatory to seawater entry.

A group of spring and fall chinook salmon were held under identical conditions of increasing water temperature over the course of smoltification. Another group of spring and fall chinook salmon were held at a constant water temperature of $8^{\circ} \mathrm{C}$ over the same period of time.

Changes in the preferred temperature of juvenile chinook salmon were associated more closely with the size (fork length) of fish than with time (days). Both spring and 
fall chinook salmon held at $8^{\circ} \mathrm{C}$ showed an increase in thermal preference of about $1^{\circ} \mathrm{C}$ as fork length increased in these respective groups. This increase in thermal preference is thought to be thermoregulatory, accelerating smolt development in fish held in inhibitory low water temperatures. Spring chinook salmon held at increasing water temperatures showed no change in thermal preference associated with smoltification. Fall chinook salmon held at increasing water temperatures displayed a large drop in thermal preference towards the end of smolt development. Differences in the thermal preference patterns of spring and fall chinook salmon during smoltification may result from local habitat adaptations, as well as seasonal differences in smolt migration. 
THERMAL PREFERENCE OF SPRING AND FALI CHINOOK SALMON (ONCORHYNCHUS TSHAWYTSCHA) DURING SMOLTIFICATION

by

Sally T. Sauter

A thesis submitted in partial fulfillment of the requirements for the degree of

\author{
MASTER OF SCIENCE \\ in \\ BIOLOGY
}

Portland State University

1996 
Thermal Preference of Spring and Fall Chinook Salmon (oncorhynchus tshawytscha) during

\author{
Smoltification
}

\title{
Introduction
}

The first vertebrates that appear in the geologic fossil record were jawless, finless fishes dating back 510 million years to the late Cambrian period of the Paleozoic Era (Minkoff 1984). Amphibians appeared later, during the Devonian period, 408 million years ago, followed by reptiles during the Carboniferous period, 360 million years ago. There is a fundamental difference in the thermal biology of these early vertebrates, their living descendents and the more recently evolved birds and mammals. Most fish, amphibia and reptiles are ectothermic animals which take on the ambient temperature of the environment rather than metabolically generating a significant amount of body heat as do birds and mammals (Hickman et al. 1984).

Commonly, the environmental niche of aquatic and terrestrial ectotherms offers a range of temperatures from which animals can select (Reynolds 1977; Crawshaw 1979). Although daily and seasonal temperature cycles affect water temperature much less than ambient air temperature, research has shown that fish and water breathing amphibians do display thermal preferences (Crawshaw et al. 1981). Fish 
have evolved behavioral patterns of thermoregulation to enhance physiological responses. Shifts in thermal preference are used by fishes to regulate rates of development and metabolism (Kwain and McCauley 1978; Magnuson et al. 1979; Wollmuth et al. 1987; Konstantinov et al. 1989). Regulation above usual preference temperatures has been found to increase the survival rate of fish infected with some pathogens (Reynolds et al. 1977a; Reynolds and Covert 1977; Reynolds 1977c). Ecological mandates, such as habitat needs, predator avoidance, intraand interspecific segregation, and migrations also alter the thermoregulatory behavior of fish (Magnuson et al. 1979).

The Salmonidae are an interesting family of fish for thermal preference studies because they represent one of the oldest lineages of teleost fish and display a wide diversity of life history strategies. For example, Pacific salmon of the genus oncorhynchus exhibit considerable interspecific variation in degree of anadromy and the behavioral aspects of juvenile emigrations (Rounsefell 1958; Hoar 1976). The general life cycle of anadromous salmonids involves an adult spawning migration starting in the Pacific Ocean, continuing up freshwater river systems, and ending at spawning grounds. Fry emerging from gravel spawning beds rear for a time in freshwater, then migrate down the river system to rich oceanic feeding grounds. Juvenile emigration of anadromous 
salmonids is associated with a period of profound physiological, morphological, and behavioral changes, collectively known as smoltification. Smoltification is a dramatic developmental period seen in juvenile anadromous salmonids as these animals prepare to abandon a hypoosmotic freshwater environment to enter seawater.

spring and fall chinook salmon are two races of Oncorhynchus tshawytscha, an anadromous salmonid fish indigenous to the Columbia River and other drainages of the west coast of North America and the northern Pacific Ocean. Spring and fall chinook salmon are reproductively isolated by differences in spawning time and habitat. Intraspecific competition between the juvenile freshwater stages of spring and fall chinook salmon is minimized by differences in rearing habitat, as well as age and seasonal timing of emigration (Healy 1991).

The numbers of Columbia River chinook salmon, like many of the other stocks of Pacific salmon have declined dramatically in recent years (Ebel et al. 1989; Nehlsen et al. 1991). Extensive hydroelectric development on the Columbia River, the destruction and degradation of rearing and spawning habitat, and other natural and man-caused environmental alterations are implicated in the decline of anadromous salmonids. Hydroelectric projects without fish passage facilities, for example Grand Coulee Dam, completed 
in 1941, have blocked access to an estimated $50 \%$ of historical anadromous salmonid habitat in inland headwaters (Ebel et al. 1989). Formation of large reservoirs on the Columbia and snake rivers has transformed lotic river habitat (flowing water with vegetated shoreline) into lentic or semi-lentic reservoir habitat (still water with low vegetation) less favorable to spawning, rearing, and migration of anadromous salmonids (Ebel et al. 1989). In addition, hydroelectric projects have reduced river flows, increasing travel time for emigrating juvenile salmonids (Berggren and Filardo 1993) and altering the seasonal thermograph of the river (Ebel et al. 1989).

In recent years, considerable research has been directed towards enhancement of Columbia River salmonid runs. One focus of this research has been juvenile emigration, as immature fish undergo smoltification prepatory to entering seawater. Differences in the early life history characteristics of spring and fall chinook salmon, and the massive ecological perturbations confronting them in the Columbia River provide important avenues for study of thermal biology. Basic research on the thermal biology of anadromous salmonids is crucial to understanding the adaptive constraints of these animals. The purpose of this research was to determine the thermal preference patterns of spring and fall chinook salmon during 
smoltification in an effort to better understand the physiological role of water temperature on smolt development and migratory behavior in each race.

\section{Materials and Methods}

\section{Animal Maintenance}

Yearling spring chinook salmon ( $\mathrm{n}=500)$ were obtained from the Little white Salmon National Fish Hatchery in Cook, Washington on January 25, 1994 and transported to the Columbia River Research Laboratory (also in Cook, Washington). Fork length of these fish averaged $122 \mathrm{~mm}$. Two 285-liter tanks located indoors received $135 \mathrm{fish}$ each. One 1500-liter tank located outdoors was stocked with $144 \mathrm{fish}$.

Upriver bright fall chinook salmon, originating from Hanford Reach stock in the Columbia River, are also reared at the Little white Salmon National Fish Hatchery. Fry from this stock $(n=500)$ were obtained from the hatchery on Tuesday March 1, 1994. Fall chinook salmon had an average fork length of $42 \mathrm{~mm}$ on this date. Upriver bright fall chinook salmon were held in two 285-liter tanks indoors, each stocked with $125 \mathrm{fish}$ and one 1500-liter outdoor tank which received $250 \mathrm{fish}$

Densities of fish in holding tanks were maintained well below recommended maximums throughout the experiments (Piper 
et al. 1986). All fish were held at well water temperature (about $6^{\circ} \mathrm{C}$ ) for a minimum of 6 weeks prior to the beginning of the study. During the study, the outdoor tank ranged from $8-10^{\circ} \mathrm{C}$ due to a slight increase in well water temperature over the summer months. Spring and fall chinook salmon held indoors were put on an increasing water temperature regimen. Water temperature was increased $2^{\circ} \mathrm{C}$ in the indoor tanks every four weeks and diverged from well water temperature beginning on April 4, 1994. Water temperature in the indoor tanks was regulated by a Watlow model series 910 water heater (Heatcon, Inc., Seattle, WA) which maintained water temperature within $1^{\circ} \mathrm{C}$. Fish in indoor tanks were exposed to a simulated natural photoperiod (SNP) which was adjusted every two weeks for the duration of the experimental period.

Differences in the size and developmental stage between the two races of chinook salmon necessitated separate feeding protocols for fall and spring chinook salmon. Spring chinook salmon were fed to satiation in the morning and late afternoon. Fall chinook salmon were fed to satiation six times daily early in the season; as the fish grew, feeding frequency was reduced to two daily feeding.

\section{Experimental Procedure}

Fish were tested in a horizontal thermal gradient 240 $\mathrm{cm}$ long and $106 \mathrm{~cm}$ wide (Figure 1). The gradient was divided into 10 chambers. Each chamber was $48 \mathrm{~cm}$ long and $30 \mathrm{~cm}$ wide 
Figure 1. The temperature gradient apparatus. Numbers represent the water temperature $\left({ }^{\circ} \mathrm{C}\right)$ of the middle of each chamber at a depth of $5 \mathrm{~cm}$. 


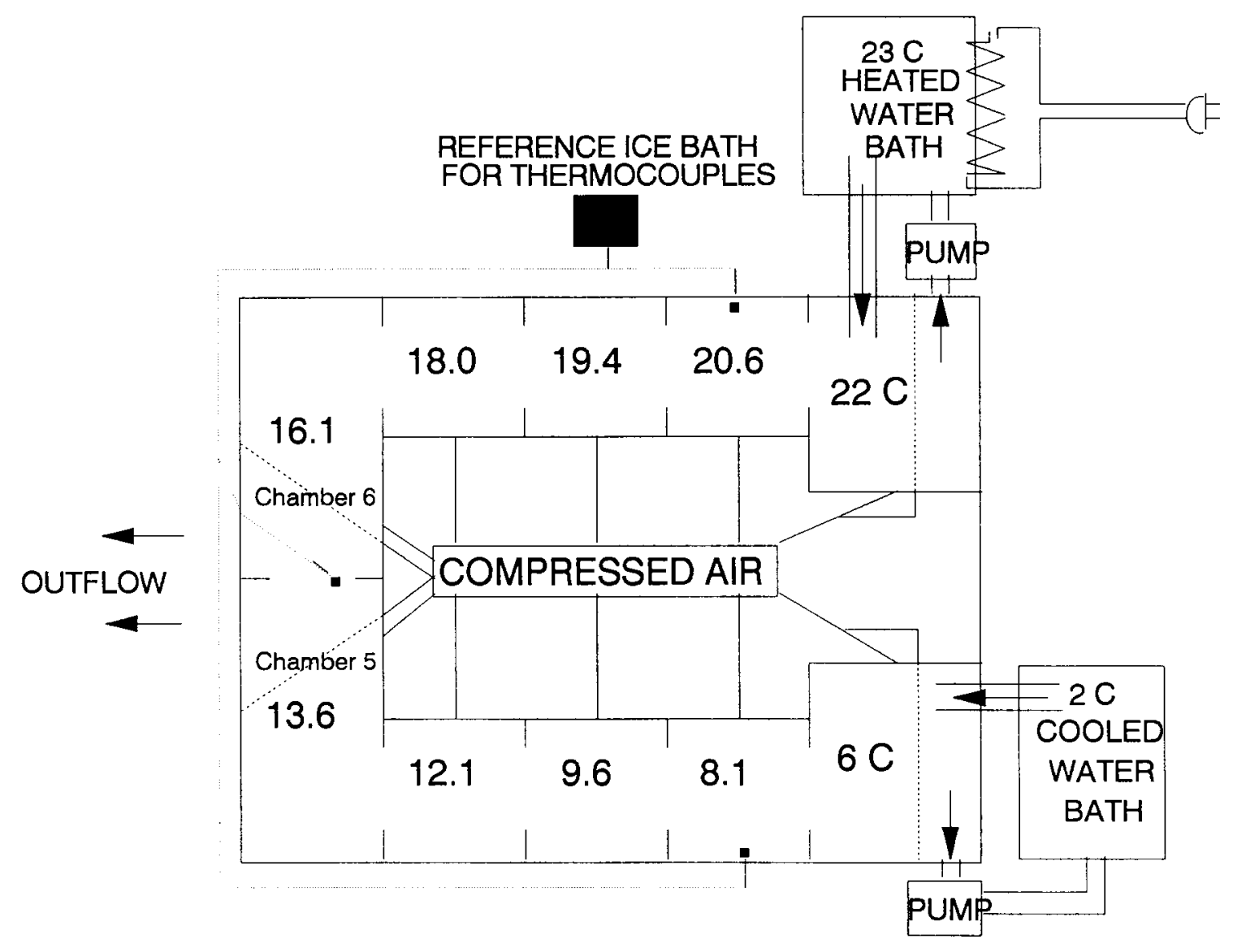

Figure 1. 
with openings $18 \mathrm{~cm}$ wide between chambers. Chamber 1 received cold water from a tank cooled by a Frigid Units (Frigid Units, Inc. Toledo, Ohio) chiller set at $1.5 \pm 0.5^{\circ}$ C. Chamber 10 received water from a tank heated to $23 \pm 0.2^{\circ}$ C (Protector 1 -- Process Technologies, Anaheim, CA). Water temperature in the gradient apparatus ranged from $6^{\circ} \mathrm{C}$ to $22^{\circ}$ C. Water flowed through the gradient at a rate of approximately $0.5 \mathrm{~cm}^{3} / \mathrm{s}$. Water was recirculated from the gradient back into the tanks with two small pump assemblies, one running from chamber 1 back into the chilled water tank and the other from chamber 10 back into the heated water tank. Fresh well water was supplied to each tank at the rate of $5 \mathrm{~cm}^{3} / \mathrm{s}$. Outflow from the gradient was from two drains 10 $\mathrm{cm}$ above the bottom of the gradient and $15 \mathrm{~cm}$ apart in chambers 5 and 6 . Air was bubbled into each chamber at equally spaced intervals to keep the water from thermally stratifying in the chambers.

Water temperature in the gradient was continuously monitored with three thermocouples connected to a chart recorder. Initial temperature calibration of the gradient was accomplished by placing a thermocouple in the cold and warm water tanks and adjusting the appropriate thermostats. Once the temperatures in the cold and warm water tanks were adjusted, one thermocouple was affixed to chamber 2 , the second thermocouple to chamber 9 and the third mid-point 
between chambers 5 and 6 (Figure 1). Twice daily, shortly after fish were introduced to the gradient and at the end of each 24-hr gradient run, temperatures were manually recorded. Manual temperature measurements were standardized using plexiglass forms that fit on the bottom of each chamber. Each plexiglass form had five slots at equal distances apart through the middle of the form. A mercury thermometer, mounted on a wand with the mercury bulb placed $5 \mathrm{~cm}$ above the bottom of the gradient was inserted into each slot in the plexiglass template. The thermometer was allowed to equilibrate, local temperature was recorded and a thermal map of the entire gradient was thus constructed. Manual temperature readings were taken for daily calibration of the chart recorder and to monitor shifts in the water temperature of each chamber over the 24 -h period.

The gradient was enclosed in a constant temperature room where fish were isolated from outside noise and all visual disturbance. During the photophase, the gradient was illuminated from above with three 40 -watt bulbs, which produced a light level between 4 and 6.5 lumen $/ \mathrm{ft}^{2}$ at the surface of the water. Two 7.5-watt infrared lights and one 7.5-watt incandescent bulb illuminated the gradient during the scotophase, producing a light level between 0.01 and 0.50 lumens $/ \mathrm{ft}^{2}$ at the surface of the water. Average natural light levels for full sunlight are approximately 100 
lumens/ft ${ }^{2}$; a clear night during the new moon provides approximately 0.10 lumens $/ \mathrm{ft}^{2}$ to the environment.

Since smoltification is a developmental period when both spring and fall chinook salmon are behaviorally oriented toward cohorts, fish were run in groups of five individuals. The thermal gradient was able to accommodate five spring chinook salmon smolts without crowding and this number of individuals was easy to differentiate on videotape. A typical gradient run began with five fish netted from a holding tank, transported in a covered bucket of water and introduced to the thermal gradient at a temperature within $1^{\circ} \mathrm{C}$ of the holding temperature. Shortly after fish were introduced to the gradient, manual temperature readings were taken. Fish were then left undisturbed in the gradient and videotaped for the remainder of the 24-h period.

Four separate groups of chinook salmon consisting of five fish each were run weekly in the thermal gradient. These groups were:

Group 1. spring chinook held at $8^{\circ} \mathrm{C}$ and natural photoperiod

Group 2. spring chinook held indoors on SNP and an increasing temperature schedule

Group 3. fall chinook held at $8^{\circ} \mathrm{C}$ and natural photoperiod 
Group 4. fall chinook held indoors on SNP and an increasing temperature schedule

Thermal preference experiments on spring chinook salmon began on Friday March 4, 1994. The two groups of spring chinook salmon were tested each week through mid-June, 1994.

On Thursday May 5, 1994, the first group of fall chinook salmon were introduced into the thermal gradient. Gradient runs on the two groups of fall chinook salmon were conducted for six months, and were terminated on August 30, 1994 .

\section{Sampling Procedure}

After 24 hours in the gradient, fish were captured and placed in a bucket with a lethal dose $(200 \mathrm{~g} / \mathrm{L})$ of tricaine methanesulfonate (MS-222). Fish were measured for fork length (mm) and weighed $(\mathrm{g})$.

To facilitate comparison of temperature preference in smolting spring and fall chinook salmon, an established, reliable smoltification marker was necessary to identify onset and completion of smoltification in the two races. Several physiological variables are known to increase during smoltification. Zaugg and McLain (1972) found an increase in salinity preference associated with increased gill $\mathrm{Na}^{+}-\mathrm{K}^{+}$ ATPase activity in spring chinook and coho salmon $(0$. kisutch). Zaugg (1981) concluded that migratory behavior and salinity tolerance develop in parallel, increasing over the 
course of smoltification. Further research by Zaugg (1982) and Rodgers et al. (1987) on hatchery and wild coho salmon established that pre-smolts have low gill $\mathrm{Na}^{+}-\mathrm{K}^{+}$ATPase values, and that gill $\mathrm{Na}^{+}-\mathrm{K}^{+}$ATPase levels begin to rise prior to migration, peak during smoltification, then decline thereafter.

Gill samples for $\mathrm{Na}^{+}-\mathrm{K}^{+}$ATPase activity were collected by removing a small amount of gill tissue with surgical scissors. Gill tissues were placed in $0.5 \mathrm{ml}$ aliquots of sucrose-disodium ethylenediamine tetraacetate-imidazole (SEI) preservative. Gill $\mathrm{Na}^{+}-\mathrm{K}^{+}$ATPase levels were determined using the microassay method of Schrock et al. (1994).

The permissive and synergistic involvement of thyroid hormones in developmental and metabolic processes has been observed throughout the vertebrate subphylum (Dickhoff and Darling 1983). Smoltification in coho salmon and larval metamorphosis in anuran amphibians are both characterized by increased plasma thyroid hormone levels coincident with transformation (Dickhoff and Darling 1983; Regard 1978). Elevated plasma thyroxine levels are associated with morphological changes (Premdas and Eales 1976), increased seawater survival (Dickhoff et al. 1982), olfactory memory and learning (Morin and Dodson 1987), migratory restlessness (Love 1980) and downstream orientation (Youngson and Simpson 1984) in smolting salmonids. In coho salmon, plasma 
thyroxine $\left(\mathrm{T}_{4}\right)$ levels have provided an index of thyroid activity reliably foreshadowing the morphological and physiological events of smoltification (Dickhoff et al. 1982; Dickhoff et al. 1978).

Blood samples for determination of plasma thyroxine levels were obtained by severing the caudal peduncle and collecting the blood in heparinized capillary tubes. Plasma thyroxine levels were determined using a radioimmunoassay method developed by Dickhoff et al. (1982) for salmonid plasma. Plasma and gill samples were immediately frozen after collection and stored at $-80^{\circ} \mathrm{C}$.

\section{Videotape Analysis}

A remote camera (Burle) with a $1: 1: 6$ lens was mounted on a rigid ceiling support above the gradient for filming. The camera was connected to a Burle TC3960A time lapse video recorder outside the gradient area. Videotapes of gradient runs were analyzed using the Jandel Scientific JAVA (Corte Madera, CA) video analysis software. The video image was calibrated so that the thermal gradient was divided into $\mathrm{x}$ and $Y$ coordinates. To record the position of a fish in the gradient, the video image was frozen, the $X, Y$ coordinates of the fish were locked in place using the computer mouse as a pointer, and the coordinates transmitted to a data file in the JAVA program. Each data set was also recorded manually onto a data sheet and checked for accuracy. 
Cartesian coordinates were taken for the position of each fish in the gradient from the video image. Individual fish position coordinates were then related to water temperature records from the gradient; the position of each fish was thus translated into a water temperature value.

$\mathrm{X}$ and $\mathrm{Y}$ coordinates from each fish were obtained from two separate one-hour intervals taken from 1:00 to 2:00 am and 3:00 to 4:00 am. The video recorder was started at the appropriate time on the videotape and the first reading was taken as soon as all five fish could be located on the monitor screen. Individual cartesian coordinates were taken on all five fish, at time intervals at least $3 \mathrm{~min}$ apart, for each hour. Locating all five fish simultaneously was sometimes difficult particularly during nighttime filming, and the next reading was delayed until all fish could be located. A typical hour of collecting $\mathrm{X}, \mathrm{Y}$ coordinates from five fish produced from 50 to 100 individual positions. When fewer than 25 individual readings on five fish could be gathered in an hour, readings with a minimum of four fish present were accepted.

\section{Data Analysis}

A series of conversions were necessary to assign water temperatures to individual fish position coordinates. The Cartesian coordinates of the corner of each gradient chamber were recorded from the Java videotape analysis program in 
the same manner that fish position coordinates were determined. Raw temperatures, recorded manually from the gradient at the end of each $24-\mathrm{h}$ gradient run were used to develop a regression equation for each of the ten gradient chambers each day. A computer program assigned individual fish position coordinates to the appropriate date and chamber. Finally, an actual temperature was calculated for each fish using the regression formula specific for the day and chamber.

\section{Statistical Analysis}

Thermal preference data lends itself to descriptive statistical analysis (Mathur et al. 1981). Frequency histograms were constructed from the thermal preference data sets for comparison of preference temperatures between the four different experimental groups. Experimental groups where mean preference temperature shifted significantly over time as mean fork lengths increased were divided into two histograms based on the mean fork length when preference temperature diverged. Mean gill $\mathrm{Na}^{+}-\mathrm{K}^{+}$ATPase and thyroxine levels were determined for each group of fish run in the gradient. Gill $\mathrm{Na}^{+}-\mathrm{K}^{+}$ATPase activity curves were constructed from weekly mean values for each of the four experimental groups. These activity curves were used as markers for smolt development to compare thermal preference within groups over the course of smoltification and between groups (which 
developed at different rates and different seasons). Mean thyroxine levels were correlated with mean gill $\mathrm{Na}^{+}-\mathrm{K}^{+}$ATPase levels to determine if increases in plasma thyroxine levels preceded changes in gill $\mathrm{Na}^{+}-\mathrm{K}^{+}$ATPase levels in chinook salmon as they do in coho salmon (Dickhoff et al. 1978).

The five fish introduced to the gradient for each $24-\mathrm{h}$ run were treated statistically as a group rather than as five individuals. Individuals were not identifiable within the group, so it was not possible to determine a separate mean preference temperature for the five fish in any gradient run. In addition, Mathur et al. (1981) states that if it is not possible to determine the effects of cohorts on individual behavior in a thermal gradient, then the group must be treated as a single entity $(n=1)$. In the present study, control runs, where water temperature was maintained at $15^{\circ} \mathrm{C}$ throughout the gradient apparatus, indicated individual fish were strongly oriented on cohorts.

Simple regression analysis was used to determine if there was a significant change $(P>F \leq 0.05)$ in mean preference temperature over time (days) in the four experimental groups. Where simple regression analysis indicated a significant change in preference temperature over time, a stepwise multiple correlation analysis was run correlating mean preference temperature with mean fork length, mean gill $\mathrm{Na}^{+}-\mathrm{K}^{+}$ATPase activity, and mean thyroxine levels. A 
probability of $\mathrm{P}>\mathrm{F} \leq 0.15$ was required for inclusion in the stepwise multiple correlation model.

Simple correlation analysis was used to determine the strength of association between mean preference temperature and mean fork length, mean gill $\mathrm{Na}^{+}-\mathrm{K}^{+}$ATPase activity, and mean thyroxine levels. Simple correlation analysis of mean gill $\mathrm{N}^{+}-\mathrm{K}^{+}$ATPase levels with mean fork length, and mean thyroxine levels were analyzed, as well as the association between mean thyroxine values and mean fork length. A $P<0.05$ significance level was used for simple regression and correlation analyses.

\section{$\underline{\text { Results }}$}

\section{Thermal Preference}

A summary of each experimental group, including acclimation temperature, range of fork lengths, and the experimental period appears in Table 1 . The difference in age at smoltification between the two races of chinook salmon, and the effect of acclimation temperature on growth rate between same race groups resulted in a different range of fork lengths during the experimental period in the four groups (Figure 2).

A mean preference temperature of $16.7^{\circ} \mathrm{C}$ (weekly mean range $=15.5-17.4^{\circ} \mathrm{C}$ ) was determined for yearling spring 
Table 1. Summary of 1994 thermal preference experiments. Fish held at increasing water temperatures are denoted as ESCH (spring chinook) and EFCH (fall chinook); fish held at a constant $8^{\circ} \mathrm{C}$ are denoted as OSCH (spring chinook) and OFCH (fall chinook). Fork lengths are given in $\mathrm{mm}$; temperatures in ${ }^{\circ} \mathrm{C}$.

\begin{tabular}{lcccc} 
Group & $\begin{array}{c}\text { Time } \\
\text { period }\end{array}$ & $\begin{array}{c}\text { Acclimation } \\
\text { temperature }\end{array}$ & $\begin{array}{c}\text { Range of } \\
\text { Mean weekly } \\
\text { fork lengths }\end{array}$ & $\begin{array}{c}\text { Range of } \\
\text { individual } \\
\text { fork lengths }\end{array}$ \\
\hline ESCH & $3 / 04-6 / 14$ & $8-14^{\circ}$ & $122.8-170.6$ & $111-175$ \\
OSCH & $3 / 09-6 / 15$ & $8^{\circ}$ & $122.6-154.0$ & $109-173$ \\
EFCH & $5 / 05-8 / 07$ & $12-18^{\circ}$ & $69.2-123.0$ & $67-132$ \\
OFCH & $5 / 13-5 / 30$ & $8^{\circ}$ & $60.2-94.6$ & $57-103$ \\
\hline
\end{tabular}


Figure 2. Preference temperature pattern of spring and fall chinook salmon showing relationship with fork length (mm) of fish. 


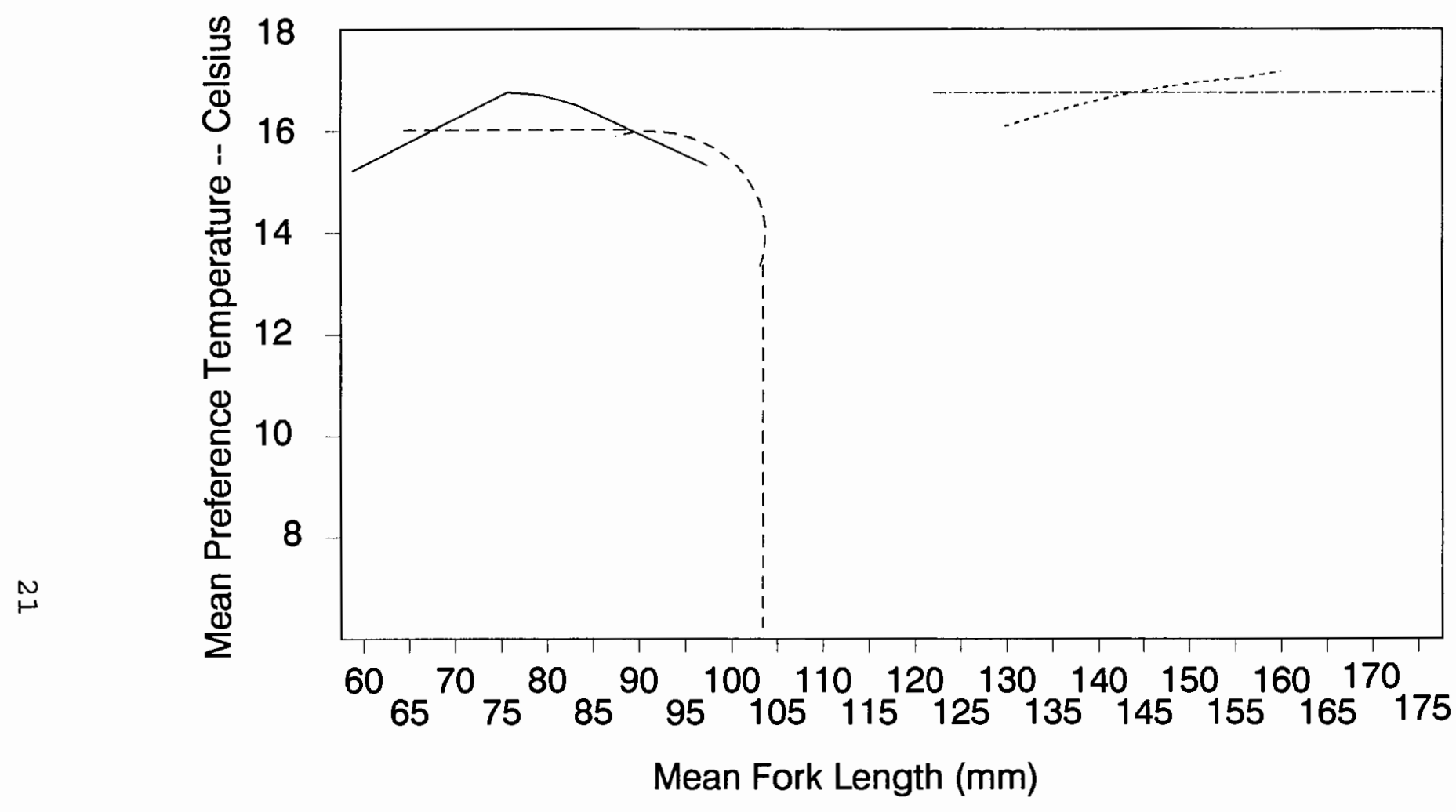

Fall Chinook Salmon -- increasing water temperature Fall Chinook Salmon -- constant $8 \mathrm{C}$
Spring Chinook Salmon -- increasing water temperature Spring Chinook Salmon -- Constant $8 \mathrm{C}$

Figure 2. 
chinook salmon held at increasing water temperatures (Table 2). Regression analysis of mean preference temperature over time (days) indicated there was no significant change in mean preference temperature over the 16 weeks of monitoring (Figure 3A) (Table 3). There was no correlation between mean preference temperature and mean fork length, or mean gill $\mathrm{Na}^{+}-\mathrm{K}^{+}$ATPase levels in this experimental group (Table 4). Weekly mean gill $\mathrm{Na}^{+}-\mathrm{K}^{+}$ATPase levels and morphological observations indicated that this group of fish completed smolt development between March 3 and June 14, 1994 (Figure 4).

Spring chinook salmon held at a constant water temperature of $8^{\circ} \mathrm{C}$ showed a mean preference temperature of $16.7^{\circ} \mathrm{C}$ (weekly mean range $\left.=15.4-17.9^{\circ} \mathrm{C}\right)($ Table 2$)$. Thermal preference studies on this group of fish took place over 15 weeks between March 9 and June 16, 1994; there was a significant change in the mean preference temperature of fish over time (days) (Figure 3B) (Table 3). Correlation analysis of mean preference temperature with mean fork length, mean gill $\mathrm{Na}^{+}-\mathrm{K}^{+}$ATPase, and mean thyroxine levels showed only mean fork length met the 0.15 significance level for entry into the stepwise multiple correlation model (Table 5). Correlation of mean preference temperature with mean fork length produced a positive correlation (Figure 5B) (Table 4). A weak correlation was demonstrated between 
Table 2. Summary of mean preference temperatures $\left({ }^{\circ} \mathrm{C}\right)$ and range of weekly mean preference temperatures during smolt development in four groups of chinook salmon. Chinook salmon held at increasing water temperatures are designated ESCH for spring and EFCH for fali chinook; fish held at a constant $8^{\circ} \mathrm{C}$ are designated OSCH for spring and OFCH for fall chinook.

\begin{tabular}{lccccc} 
Group & $\begin{array}{c}\text { No. of } \\
\text { weeks }\end{array}$ & $\begin{array}{c}\text { No. of } \\
\text { readings }\end{array}$ & $\begin{array}{c}\text { Mean } \\
\text { preference } \\
\text { temperature }\end{array}$ & $\begin{array}{c}\text { Standard } \\
\text { deviation }\end{array}$ & $\begin{array}{c}\text { Range of mean } \\
\text { preference } \\
\text { temperature }\end{array}$ \\
\hline ESCH & 16 & 2802 & $16.7^{\circ}$ & 2.81 & $15.5^{\circ}-17.4^{\circ}$ \\
OSCH & 15 & 2855 & $16.7^{\circ}$ & 2.06 & $15.4^{\circ}-17.9^{\circ}$ \\
EFCH & 15 & 2002 & $15.5^{\circ}$ & 3.54 & $10.8^{\circ}-17.8^{\circ}$ \\
OFCH & 17 & 2488 & $16.5^{\circ}$ & 1.50 & $15.2^{\circ}-17.7^{\circ}$
\end{tabular}


Figure 3. Linear regression analyses of mean preference temperature over time (days) in spring chinook salmon held at increasing water temperatures $(A)$ and at $8^{\circ} \mathrm{C}(\mathrm{B})$ during smolt development. 

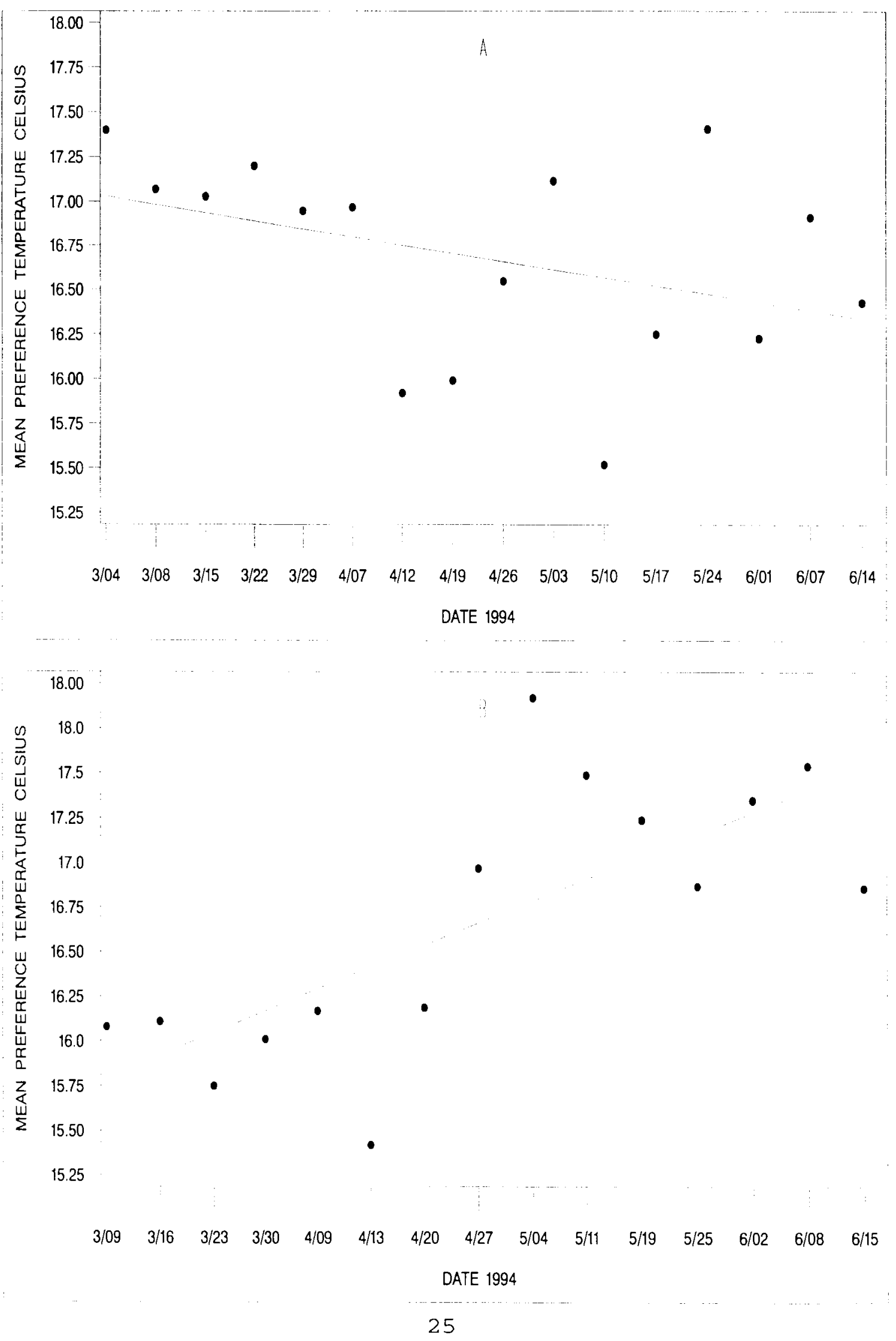
Table 3. Simple linear regression of mean preference temperatures over time (days). Adjusted coefficient of determination $\left(r^{2}\right)$, number of samples (N), degrees of freedom (DF), and probability of significant regression (P) are given. Spring and fall chinook salmon held at increasing water temperatures are designated ESCH and EFCH, respectively. Spring and fall chinook salmon held at a constant $8^{\circ} \mathrm{C}$ are designated $\mathrm{OSCH}$ and $\mathrm{OFCH}$.

\begin{tabular}{llllll} 
Group & $N$ & DF & $r^{2}$ & $P$ \\
\hline ESCH & 16 & 15 & 0.0838 & 0.1458 \\
OSCH & 15 & 14 & 0.5011 & 0.0019 \\
EFCH & 15 & 14 & 0.5914 & 0.0029 \\
OFCH & 17 & 16 & 0.0430 & 0.2321 \\
\hline
\end{tabular}


Table 4. Variable, correlation equation, adjusted coefficient of determination $\left(r^{2}\right)$, probability of significant correlation (P), and sample size (N), of weekly mean preference temperature ( $Y$ ) correlated with mean fork length (FL), mean gill $\mathrm{Na}^{+}-\mathrm{K}^{+}$ATPase (ATPase), and mean plasma thyroxine $\left(\mathrm{T}_{4}\right)$ levels. ESCH and EFCH denote spring and fall chinook salmon held at increasing water temperatures; OSCH and OFCH denote spring and fall chinook salmon held at $8^{\circ} \mathrm{C}$. Linear or curvilinear models were applied for best fit.

\begin{tabular}{|c|c|c|c|c|c|}
\hline Group & Variable & $\mathrm{N}$ & $r^{2}$ & $P$ & Correlation Equation \\
\hline \multirow[t]{3}{*}{$\mathrm{ESCH}$} & FL & 16 & 0.0835 & 0.2777 & $y=18.1613-0.0103 \cdot F L$ \\
\hline & ATPase & 16 & -0.0255 & 0.4416 & $\begin{aligned} \mathrm{y}=17.1768- \\
0.0560 \cdot \text { ATPase }\end{aligned}$ \\
\hline & $\mathrm{T}_{4}$ & 16 & -0.0769 & 0.9777 & $\mathrm{Y}=16.6908-0.0014 \cdot \mathrm{T}_{4}$ \\
\hline \multirow[t]{3}{*}{$\mathrm{OSCH}$} & FL & 15 & 0.4479 & 0.0038 & $y=9.1010+0.0539 \cdot F L$ \\
\hline & ATPase & 15 & 0.2792 & 0.0249 & $\begin{array}{l}y=15.1653+ \\
0.1329 \cdot \text { ATPase }\end{array}$ \\
\hline & $\mathrm{T}_{4}$ & 15 & -0.0743 & 0.8626 & $Y=16.8018-0.0125 \cdot T_{4}$ \\
\hline \multirow[t]{3}{*}{$\mathrm{EFCH}$} & FL & 15 & 0.7014 & 0.0013 & $\begin{array}{c}\mathrm{Y}=-11.7855+0.6845 \cdot \mathrm{FL} \\
-0.0041 \cdot \mathrm{FL}^{2}\end{array}$ \\
\hline & ATPase & 15 & -0.0410 & 0.4983 & $\begin{array}{l}y=17.3780- \\
0.1378 \cdot \text { ATPase }\end{array}$ \\
\hline & $\mathrm{T}_{4}$ & 15 & -0.0759 & 0.5965 & $\begin{array}{c}\mathrm{Y}=21.0275-0.3236 \cdot \mathrm{T}_{4} \\
+0.3412 \cdot \mathrm{T}_{4}{ }^{2}\end{array}$ \\
\hline \multirow[t]{3}{*}{$\mathrm{OFCH}$} & FL & 17 & 0.7632 & 0.0001 & $\begin{array}{c}\mathrm{Y}=-18.7480+0.9160 \cdot \mathrm{FL} \\
-0.0058 \cdot \mathrm{FL}^{2}\end{array}$ \\
\hline & AtPase & 17 & -0.0013 & 0.3380 & $\begin{array}{l}y=15.5507+ \\
0.0819 \cdot \text { ATPase }\end{array}$ \\
\hline & $\mathrm{T}_{4}$ & 17 & 0.0263 & 0.3446 & $\begin{array}{c}\mathrm{y}=15.4466+0.2916 \cdot \mathrm{T}_{4} \\
-0.0162 \cdot \mathrm{T}_{4}{ }^{2}\end{array}$ \\
\hline
\end{tabular}


Figure 4. Weekly mean gill $\mathrm{Na}^{+}-\mathrm{K}^{+}$ATPase and mean plasma thyroxine activity for spring chinook salmon held at increasing water temperatures during smolt development. 


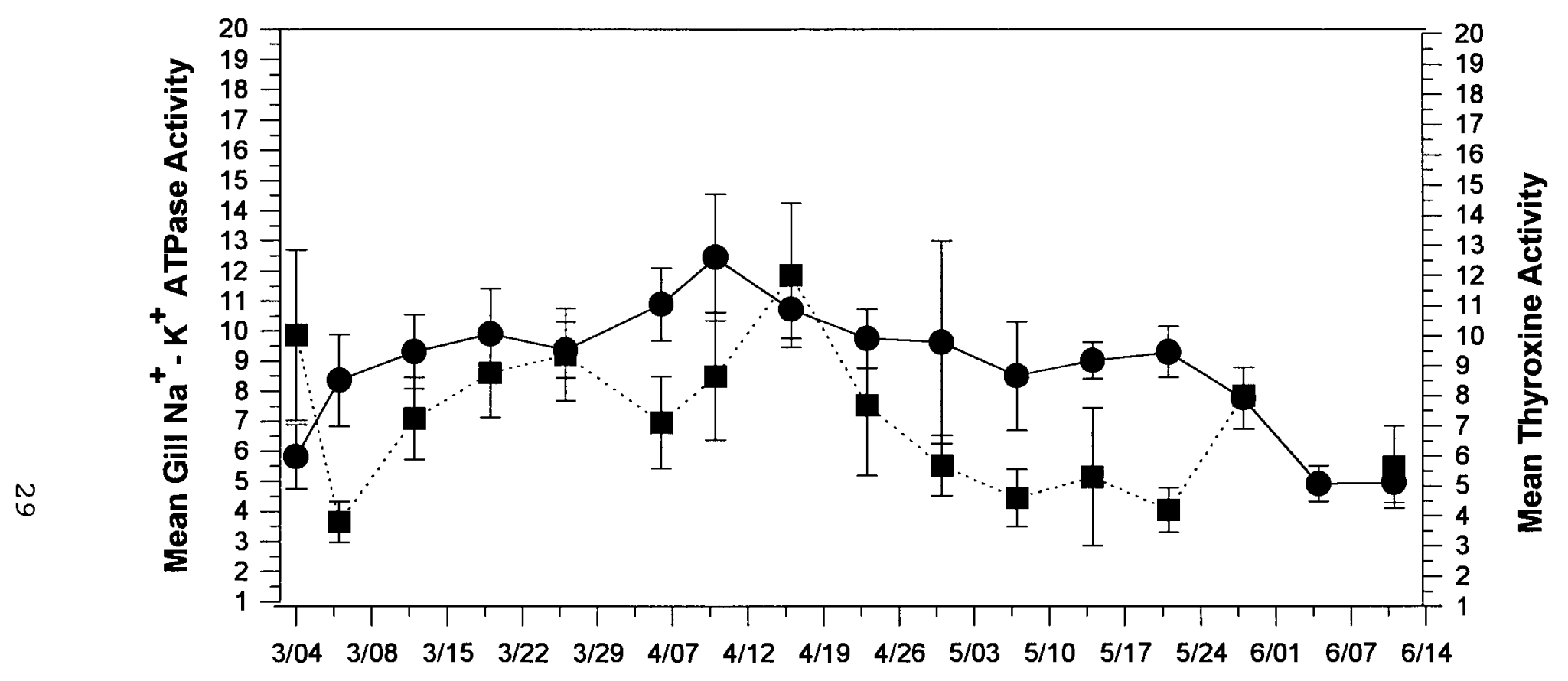

Date 1994

... Mean Thyroxine Activity

Figure 4. 
Table 5. Stepwise multiple regression of mean preference temperature (MEANTEMP) on mean fork length (FL), and mean gill $\mathrm{Na}^{+}-$ $\mathrm{K}^{+}$ATPase (ATPase) level. Spring and fall chinook salmon held at increasing water temperatures are designated ESCH and EFCH, respectively. Spring and fall chinook salmon held at a constant $8^{\circ}$ $\mathrm{C}$ are designated $\mathrm{OSCH}$ and $\mathrm{OFCH}$, respectively.

\begin{tabular}{|c|c|c|c|c|c|}
\hline Group & Equation & $\mathrm{N}$ & $r^{2}$ & $C(p)$ & Prob $>F$ \\
\hline ESCH & $\begin{array}{l}\text { No variable met the } 0.15 \text { sign } \\
\text { into the model. }\end{array}$ & aifi & sance $l e$ & vel for & entry \\
\hline OSCH & MEANTEMP $=8.9133+0.0552 \cdot \mathrm{FL}$ & 14 & 0.4908 & 1.1742 & 0.0036 \\
\hline $\mathrm{EFCH}$ & MEANTEMP $=24.6860-0.0991 \cdot \mathrm{FL}$ & 13 & 0.5327 & 4.1963 & 0.0030 \\
\hline & $\begin{array}{rl}\text { MEANTEMP }=23 & .5717-0.1383 \cdot \mathrm{FL} \\
& +0.3156 \cdot \text { ATPase }\end{array}$ & 13 & 0.6543 & 2.5037 & 70.0029 \\
\hline OFCH & \multicolumn{5}{|c|}{$\begin{array}{l}\text { No variable met the } 0.15 \text { significance level for entry } \\
\text { into the model. }\end{array}$} \\
\hline
\end{tabular}


Figure 5. Linear correlation analyses of mean preference temperature with mean fork length (mm) in spring chinook salmon held at increasing water temperatures (A) and at a constant $8^{\circ} \mathrm{C}(\mathrm{B})$. 

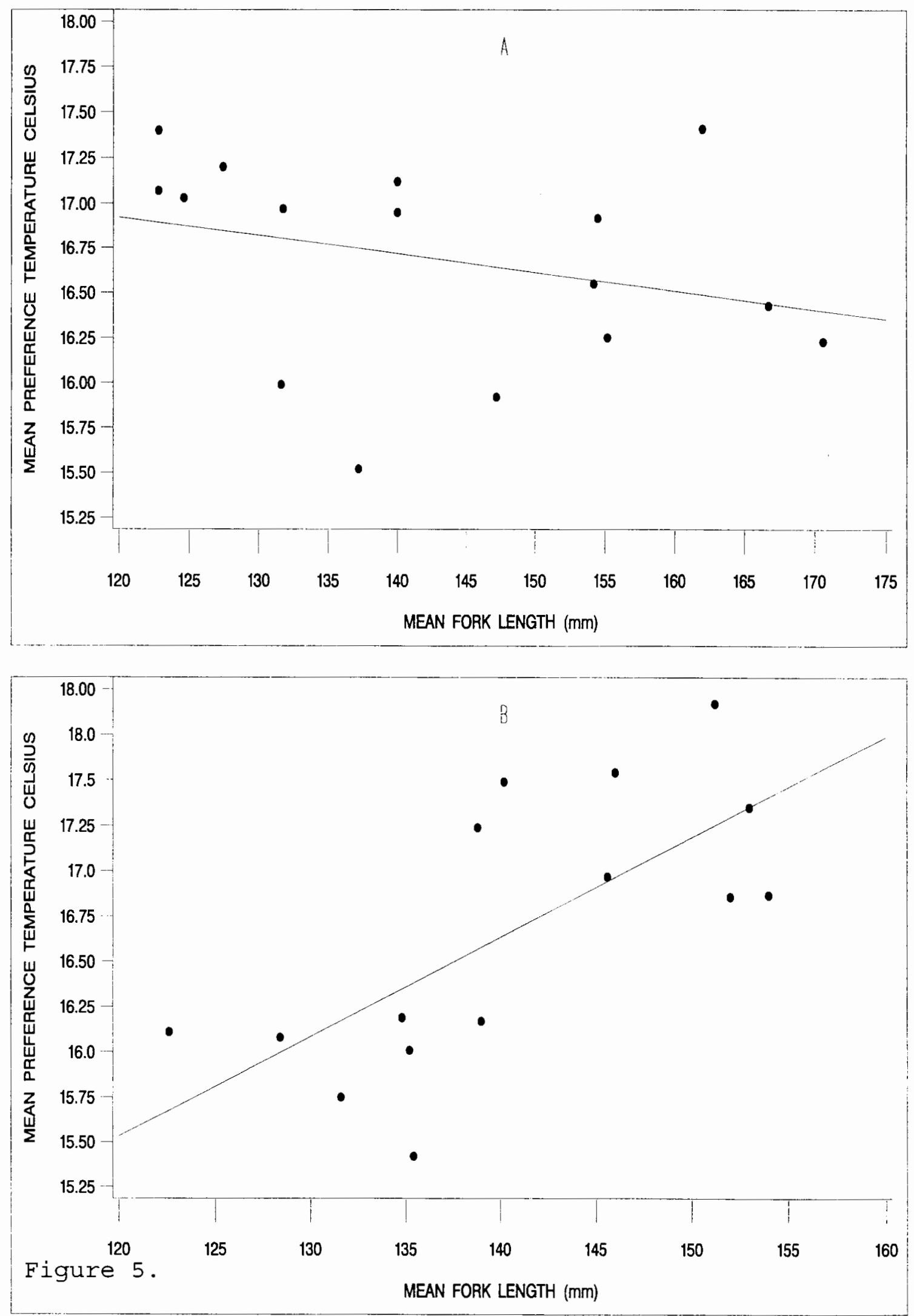
mean preference temperature and mean gill $\mathrm{Na}^{+}-\mathrm{K}^{+}$ATPase levels (Table 4). Mean gill $\mathrm{Na}^{+}-\mathrm{K}^{+}$ATPase activity rose slowly over 15 weeks and had not returned to pre-smolt levels when thermal preference experiments ended on this group of fish June 15, 1994 (Figure 6). Visually, both groups of spring chinook salmon showed signs of reverting back to parr-like characteristics by mid-June.

Subyearling fall chinook salmon held at increasing water temperatures had a mean preference temperature of $15.5^{\circ} \mathrm{C}$ (weekly mean range $=10.8-17.8^{\circ} \mathrm{C}$ ) over 15 weeks from May 5 to August 7, 1994 (Table 2). There was a significant change in mean preference temperature over time (days) in this group of fish (Figure 7A) (Table 3). Stepwise multiple correlation analysis of mean preference temperature with mean fork length, mean gill $\mathrm{Na}^{+}-\mathrm{K}^{+}$ATPase levels, and mean thyroxine levels found mean fork length and mean $\mathrm{Na}^{+}-\mathrm{K}^{+}$ ATPase significant at the 0.15 level (Table 5). Linear stepwise multiple correlation analysis did not fit the data as well as a simple curvilinear correlation model set to each variable. The simple curvilinear model resulted in a higher coefficient of determination for mean fork length alone as compared to the stepwise multiple correlation analysis for mean preference temperature with mean fork length and mean $\mathrm{Na}^{+}-\mathrm{K}^{+}$ATPase level. There was a strong negative curvilinear correlation between mean preference 
Figure 6. Weekly mean gill $\mathrm{Na}^{+}-\mathrm{K}^{+}$ATPase and mean plasma thyroxine activity for spring chinook salmon held at a constant $8^{\circ} \mathrm{C}$ during smolt development. Each point represents $\mathrm{n}=5$, thyroxine points without $\pm \mathrm{SE}$ were obtained from pooled plasma samples from 5 fish. 


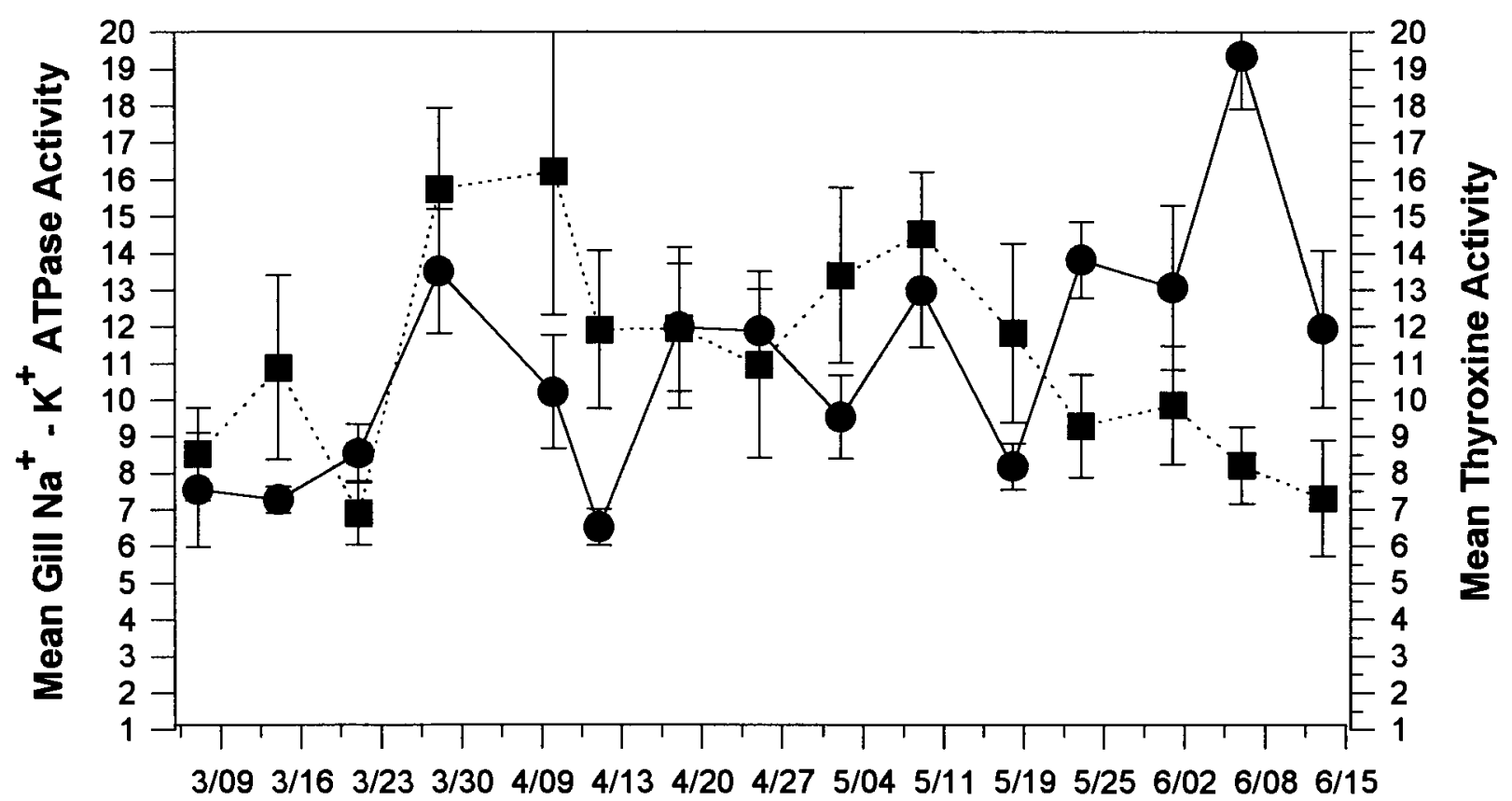

Date 1994

Mean Gill $\mathrm{Na}^{+}-\mathrm{K}^{+}$ATPase Activity Mean Thyroxine Activity 
Figure 7. Curvilinear regression analyses over time (days) with mean fork length in fall chinook salmon held at increasing water temperatures (A) and at $8^{\circ} \mathrm{C}(\mathrm{B})$ during smolt development. Each point represents the mean preference temperature of $5 \mathrm{fish}$. 

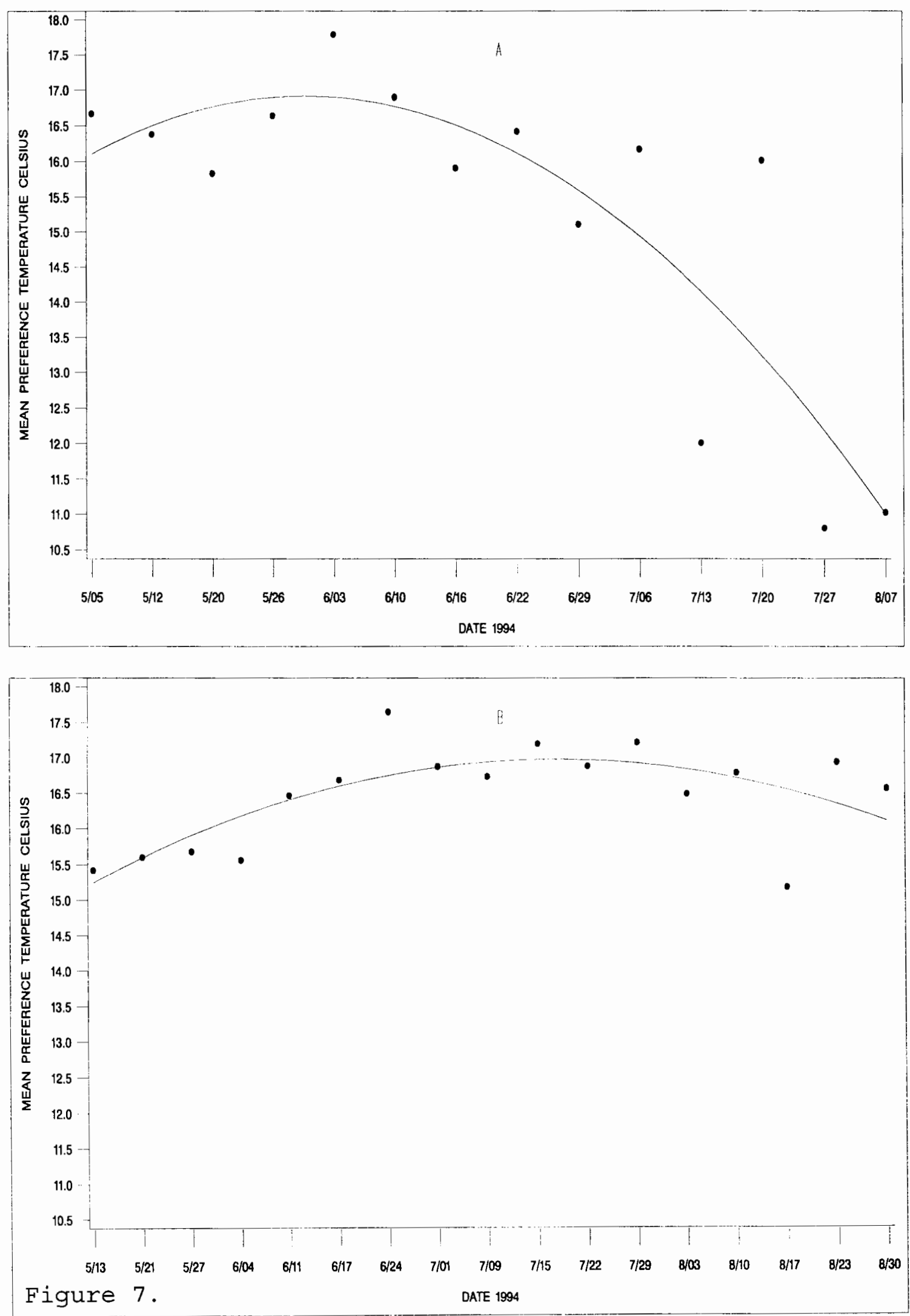
temperature and mean fork length in this group of $\mathrm{fish}$ (Figure 8A) (Table 4). No linear or curvilinear correlation was found between mean preference temperature and mean gill $\mathrm{Na}^{+}-\mathrm{K}^{+}$ATPase (Table 4). Visual characteristics consistent with smolt development were first observed in late April, when a distinctive deep-bodied appearance and an increase in scale silvering was noted. These changes in appearance coincided with an upward trend in mean gill $\mathrm{Na}^{+}-\mathrm{K}^{+}$ATPase levels between May 5 and June 3, 1994 (Figure 9). Experiments ended on August 4, 1994 before mean gill $\mathrm{Na}^{+}-\mathrm{K}^{+}$ ATPase levels had returned to pre-smolt levels, due to depletion of stock fish.

Fall chinook salmon held at $8^{\circ} \mathrm{C}$ had a mean preference temperature of $16.5^{\circ} \mathrm{C}$ (weekly mean range $=15.2-17.7^{\circ}$ ) over 17 weeks from May 13 to August 30, 1994 (Table 2). No significant change in mean preference temperature was found over time (days) in this group of fish (Figure 7B) (Table 3). There was a strong negative curvilinear correlation between mean preference temperature and mean fork length (Figure 8B) (Table 4). The curvilinear temperature pattern was distinct from that seen in fall chinook salmon held at increasing water temperatures (Figure 8A). No correlation was found between mean preference temperature and mean gill $\mathrm{Na}^{+}-\mathrm{K}^{+}$ATPase values (Table 4). Mean gill $\mathrm{Na}^{+}-\mathrm{K}^{+}$ATPase activity increased over 22 weeks, and had not returned to 
Figure 8. Curvilinear correlation analyses of mean preference temperature with mean fork length in fall chinook salmon held at increasing water temperatures (A) and at $8^{\circ} \mathrm{C}$ (B) during smolt development. Each point represents the mean preference temperature of 5 fish. 

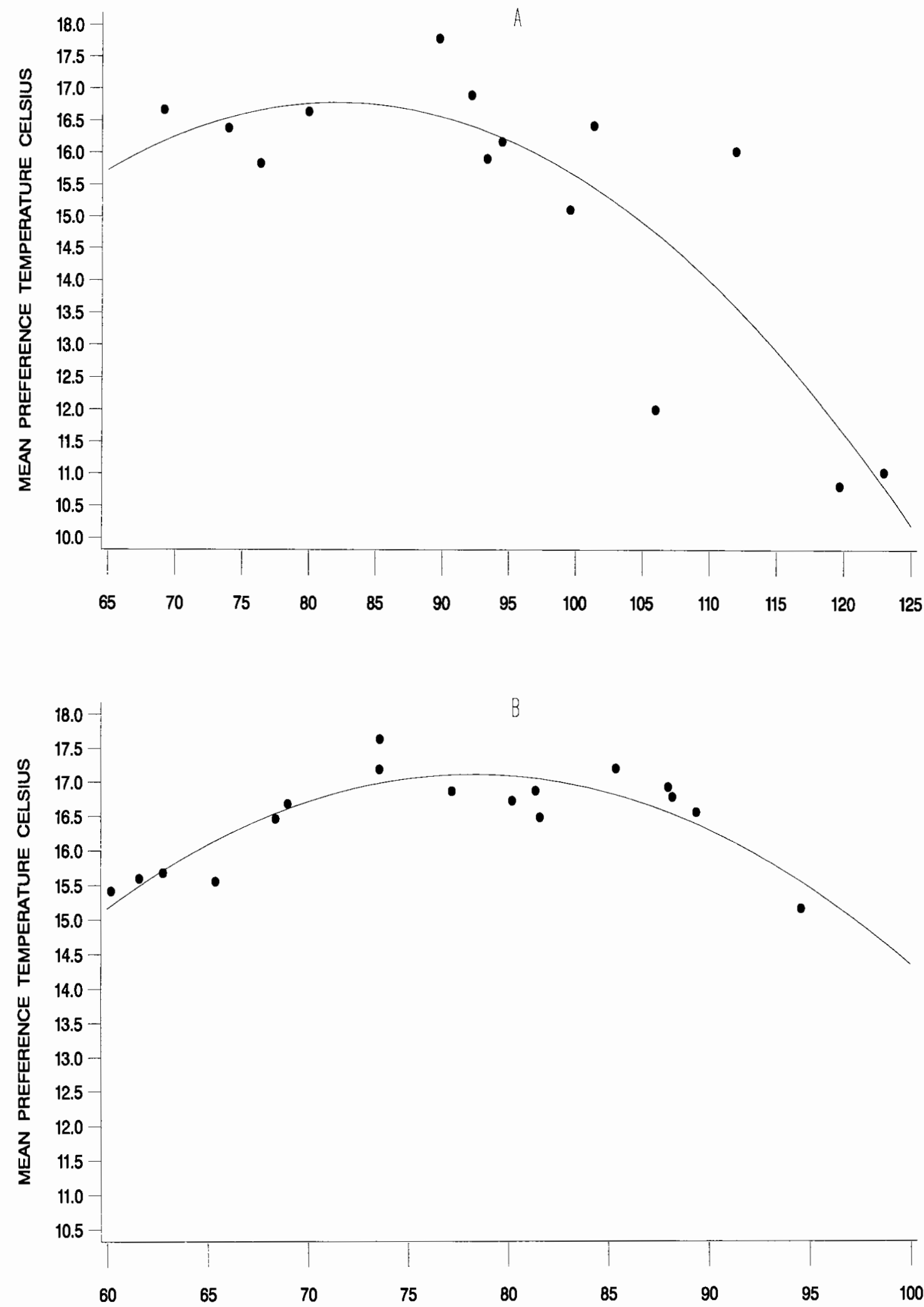

Figure 8 . MEAN FORK LENGTH (mm) 
Figure 9. Weekly mean gill $\mathrm{Na}^{+}-\mathrm{K}^{+}$ATPase and mean plasma thyroxine activity for fall chinook salmon held at increasing water temperatures during smolt development. Each point represents $n=5$, thyroxine points without $\pm S E$ were obtained from pooled plasma samples from 5 fish. 


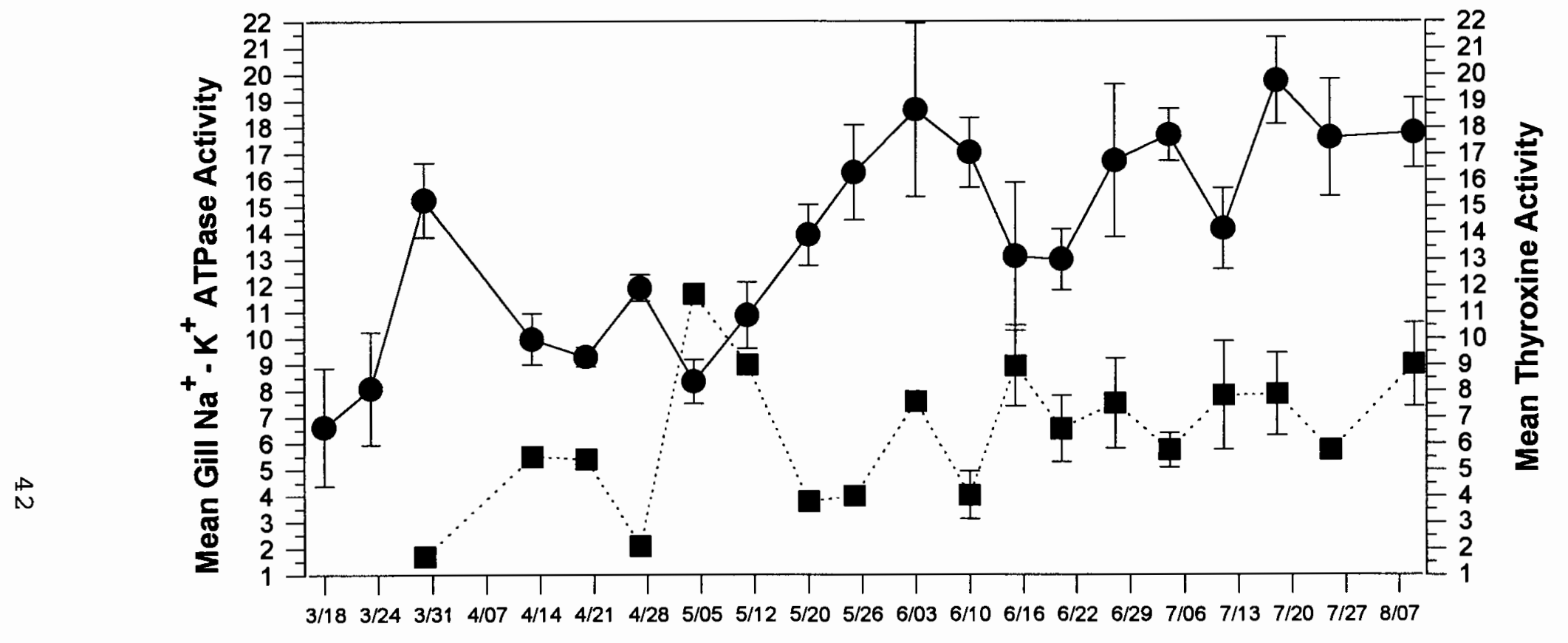

Date 1994

Mean Thyroxine Activity

Mean Gill $\mathrm{Na}^{+}-\mathrm{K}^{+}$ATPase Activity 
pre-smolt levels when experiments ended August 30, 1994 (Figure 10). Visually, these animals also displayed the deep-bodied appearance and increased silvering characteristic of smolt development.

Frequency Distributions

The frequency distribution of preference temperatures for spring chinook salmon held at increasing water temperatures appears in Figure 11. Holding temperature increased from 8 to $14^{\circ} \mathrm{C}$ and weekly mean fork lengths of fish ranged from 122.8 to $170.6 \mathrm{~mm}$ during the 16-week period. All preference temperature observations have been combined for this group of fish since no significant change in mean preference temperature occurred. A majority of observations (35.69\%) were recorded between 18.01 and $19.5^{\circ}$ C. A large number of observations also occurred in the two class intervals between 15.01 and $18.0^{\circ} \mathrm{C}$ (35.18\%). A smaller number of observations were recorded in class interval 13.51 to $15.0^{\circ} \mathrm{C}(10.46 \%)$. Small percentages of fish were observed at or below $13.5^{\circ} \mathrm{C}(10.70 \%)$ and above $19.5^{\circ} \mathrm{C}(5.68 \%)$.

Spring chinook salmon held at $8^{\circ} \mathrm{C}$ showed a positive correlation between mean preference temperature and mean fork length, therefore the frequency distribution was divided into two parts based on the mean fork length when preference temperature shifted upward at approximately 139 
Figure 10. Weekly mean gill $\mathrm{Na}^{+}-\mathrm{K}^{+}$ATPase and mean plasma thyroxine activity for fall chinook salmon held at $8^{\circ} \mathrm{C}$ during smolt development. Each point represents $n=5$, thyroxine points without SE were obtained from pooled plasma samples from 5 fish. 


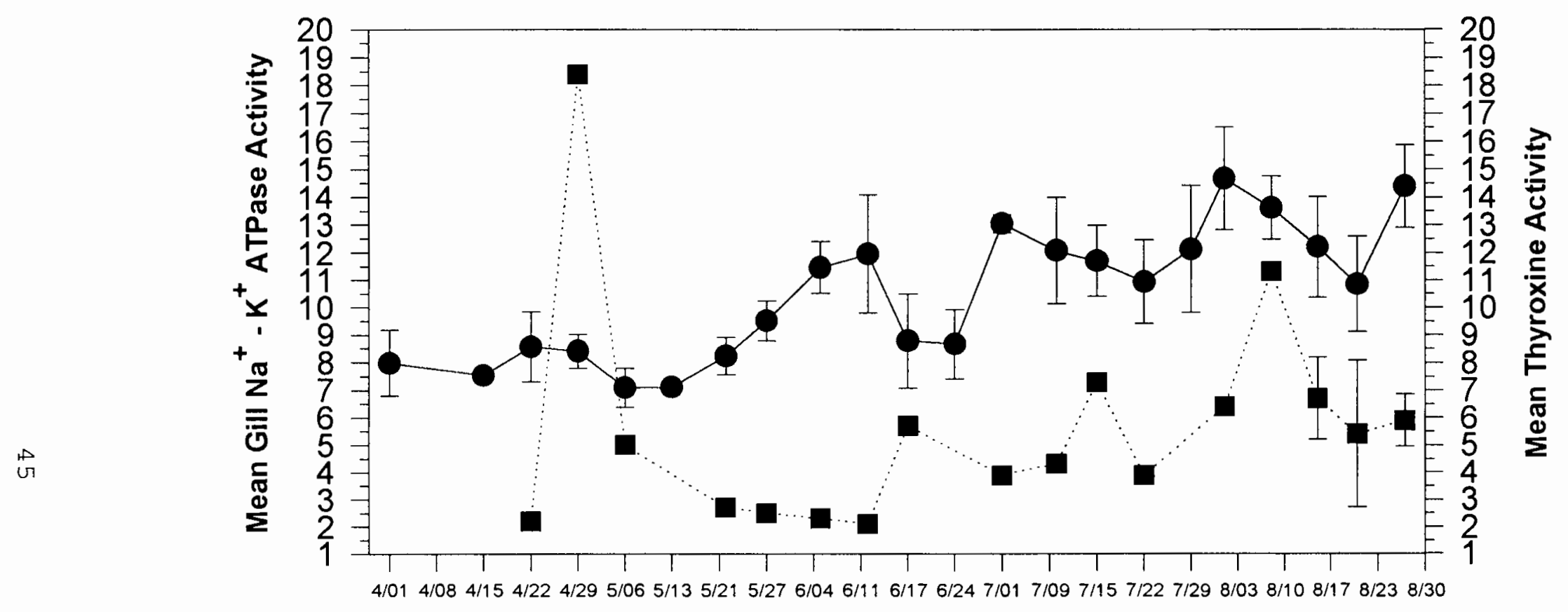

Date 1994

-.. Mean Thyroxine Activity

Mean $\mathrm{Na}^{+}-\mathrm{K}^{+}$ATPase Activity 
Figure 11. Frequency distribution of preference temperatures for spring chinook salmon held at increasing water temperatures. Preference temperature observations were collected for 16 consecutive weeks from $3 / 04 / 94$ to $6 / 14 / 94$. 


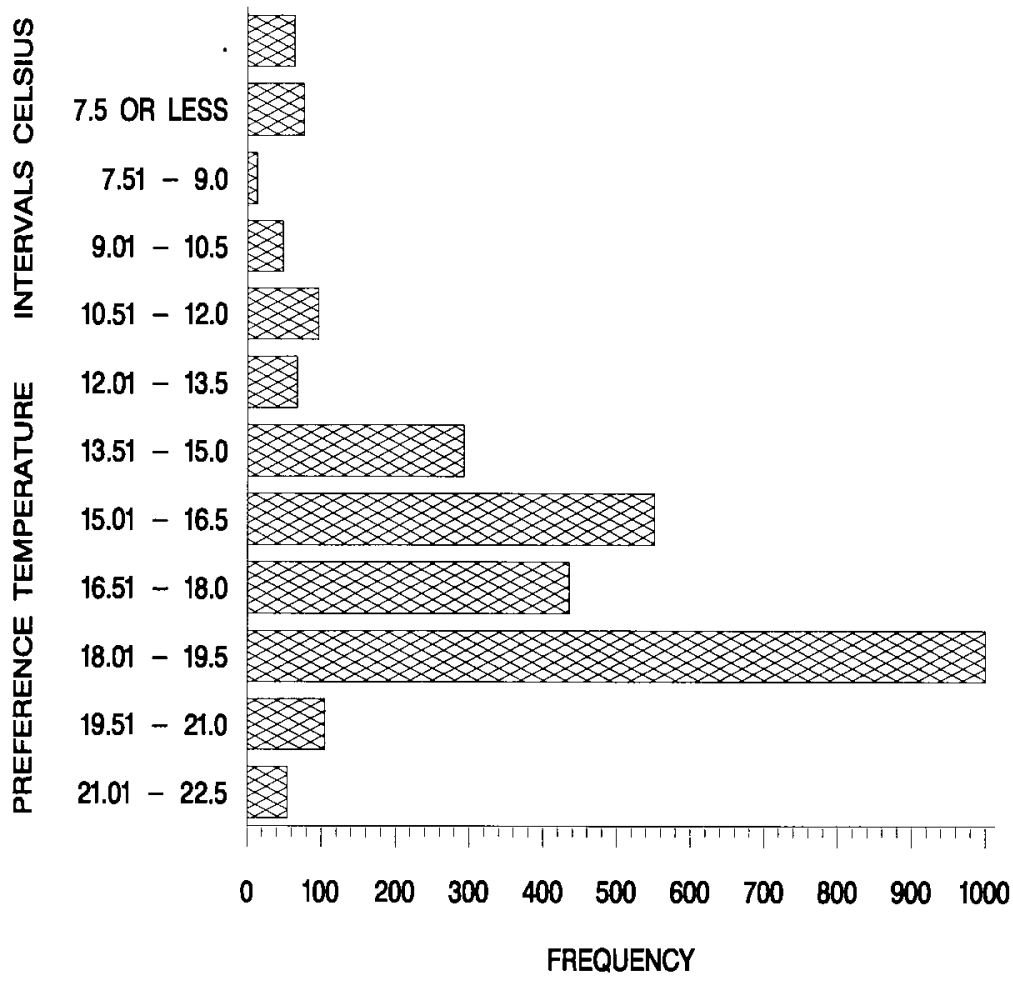

Figure 11.

\begin{tabular}{rrrr} 
FREQ. & FUM. & & CUM. \\
64 & 64 & 2.28 & 2.28 \\
76 & 140 & 2.71 & 5.00 \\
13 & 153 & 0.46 & 5.46 \\
48 & 201 & 1.71 & 7.17 \\
96 & 297 & 3.43 & 10.60 \\
67 & 364 & 2.39 & 12.99 \\
293 & 657 & 10.46 & 23.45 \\
551 & 1208 & 19.66 & 43.11 \\
435 & 1643 & 15.52 & 58.64 \\
1000 & 2643 & 35.69 & 94.33 \\
105 & 2748 & 3.75 & 98.07 \\
54 & 2802 & 1.93 & 100.00 \\
& & & \\
& & & \\
\hline 50 & & &
\end{tabular}


$\mathrm{mm}$ (Figure 5B). These fish showed the highest number of observations in the class interval 15.01 to $16.5^{\circ} \mathrm{C}(27.43 \%)$ (Figure 12A). A large percentage of observations were also recorded in intervals 13.51 to $15.0^{\circ} \mathrm{C}(23.76 \%)$, and 18.01 to $19.5^{\circ} \mathrm{C}(22.15 \%)$. A lesser number of observations were seen in the class interval between 16.51 and $18.0^{\circ} \mathrm{C}$ $(11.08 \%)$. Few fish were recorded at or below $10.5^{\circ} \mathrm{C}(1.08 \%)$ or above $19.51^{\circ} \mathrm{C}(1.76 \%)$. The groups of fish with mean fork lengths $\geq 139 \mathrm{~mm}$ displayed an increase in preference temperature of about $1^{\circ} \mathrm{C}$, based on visual observation of the regression line (Figure 5B), when compared to groups with mean fork lengths < $139 \mathrm{~mm}$. A majority of observations were recorded in temperature intervals 18.01 to $19.5^{\circ} \mathrm{C}$ $(41.91 \%), 16.51$ to $18.0^{\circ} \mathrm{C}(23.54 \%)$ and 15.01 to $16.5^{\circ} \mathrm{C}$ $(24.71 \%)$ (Figure 12B). Few fish were observed at or below $15.0^{\circ} \mathrm{C}(8.02 \%)$ or above $19.5^{\circ} \mathrm{C}(1.81 \%)$.

Fall chinook salmon held at increasing water temperatures showed a significant correlation between mean preference temperature and mean fork length (Figure 7A). Data were divided into two frequency distributions based on mean fork length when preference temperature declined in this experimental group, based on visual observation of the regression curve. Groups of fall chinook salmon with mean fork lengths < $105 \mathrm{~mm}$ were observed most frequently in class intervals 18.01 to $19.5^{\circ} \mathrm{C}(41.80 \%)$, and 16.51 to $18.0^{\circ} \mathrm{C}$ 
Figure 12. Frequency distributions of preference temperatures for spring chinook salmon held at $8^{\circ} \mathrm{C}$. Individual preference temperature observations were collected for 7 consecutive weeks when mean fork length of gradient run fish was < $139 \mathrm{~mm}$ (A), and for 8 consecutive weeks when mean fork length of fish was $\geq 139 \mathrm{~mm}$ (B). 

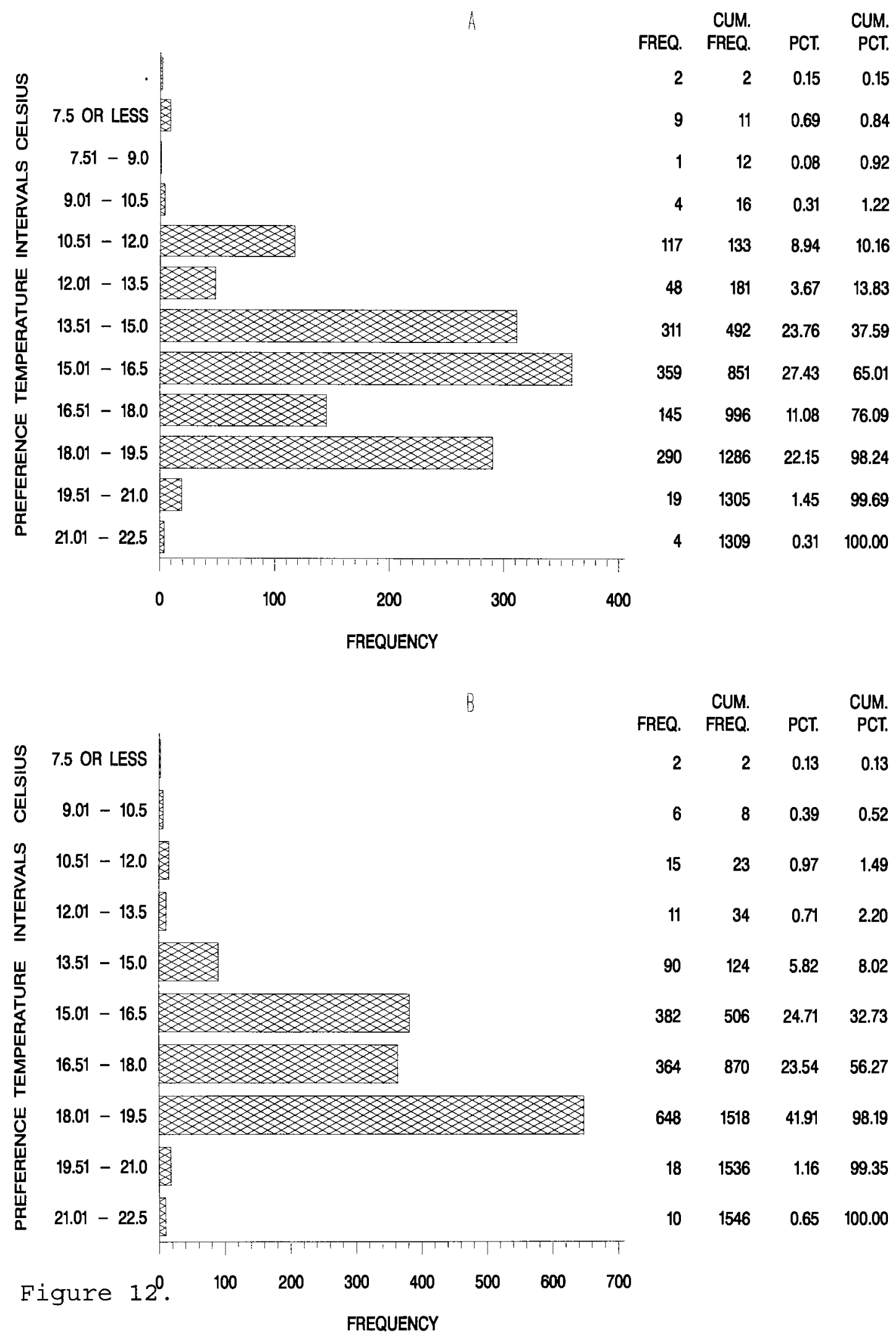

$\begin{array}{rrrr}\text { FREQ. } & \begin{array}{r}\text { CUM. } \\ \text { FREQ. }\end{array} & \text { PCT. } & \text { PCT. } \\ 2 & 2 & 0.13 & 0.13 \\ 6 & 8 & 0.39 & 0.52 \\ 15 & 23 & 0.97 & 1.49 \\ 11 & 34 & 0.71 & 2.20 \\ 90 & 124 & 5.82 & 8.02 \\ 382 & 506 & 24.71 & 32.73 \\ 364 & 870 & 23.54 & 56.27 \\ 648 & 1518 & 41.91 & 98.19 \\ 18 & 1536 & 1.16 & 99.35 \\ 10 & 1546 & 0.65 & 100.00\end{array}$


$(20.86 \%)$ (Figure 13A). The class interval between 13.51 and $15.0^{\circ} \mathrm{C}$ comprised $17.98 \%$ of observations, while the interval 15.01 to $16.5^{\circ} \mathrm{C}$ accounted for $8.03 \%$. Class interval 12.01 to $13.5^{\circ} \mathrm{C}$ made up $4.39 \%$ of recorded observations. A smaller percentage of observations were found at or below $12^{\circ} \mathrm{C}$ $(5.90 \%)$ and above $19.5^{\circ} \mathrm{C}(0.96 \%)$. Groups of fall chinook salmon with mean fork lengths $\geq 105 \mathrm{~mm}$ displayed a different thermal preference frequency distribution than groups with mean fork lengths < $105 \mathrm{~mm}$ (Figure 13B). A large percentage of observations occurred in class interval $\leq 7.5^{\circ} \mathrm{C}$ $(28.62 \%)$, and in interval 13.51 to $15.0^{\circ} \mathrm{C}(24.77 \%)$. The four class intervals between 7.51 and $13.5^{\circ} \mathrm{C}$ accounted for $17.43 \%$ of observations. Observations in the five class intervals over $15^{\circ} \mathrm{C}$ totaled $29.17 \% ; 17.25 \%$ were recorded in the interval 16.51 to $18.0^{\circ} \mathrm{C}, 9.17 \%$ were recorded in 18.01 to $19.5^{\circ} \mathrm{C}$, and $2.20 \%$ were recorded in 15.01 to $16.5^{\circ} \mathrm{C}$. Only $0.55 \%$ of observations occurred over $19.5^{\circ} \mathrm{C}$.

Fall chinook salmon held at a constant water temperature of $8^{\circ} \mathrm{C}$ showed a thermal preference distribution pattern distinct from that of fish held at increasing water temperatures (Figure 14). There was no significant change in preference temperature over time in this group of fish, so all observations taken from May 13 through August 30, 1994 were included in one distribution. The largest percentage of observations were recorded in class intervals 15.01 to $16.5^{\circ}$ 
Figure 13. Frequency distributions of mean preference temperatures for fall chinook salmon held at increasing water temperatures. Individual preference temperature observations were collected for 11 consecutive weeks when mean fork lengths of gradient run fish were $<105 \mathrm{~mm}$ (A) and for 4 consecutive weeks when mean fork lengths of gradient run fish were $\geq 105$ mm (B) . 


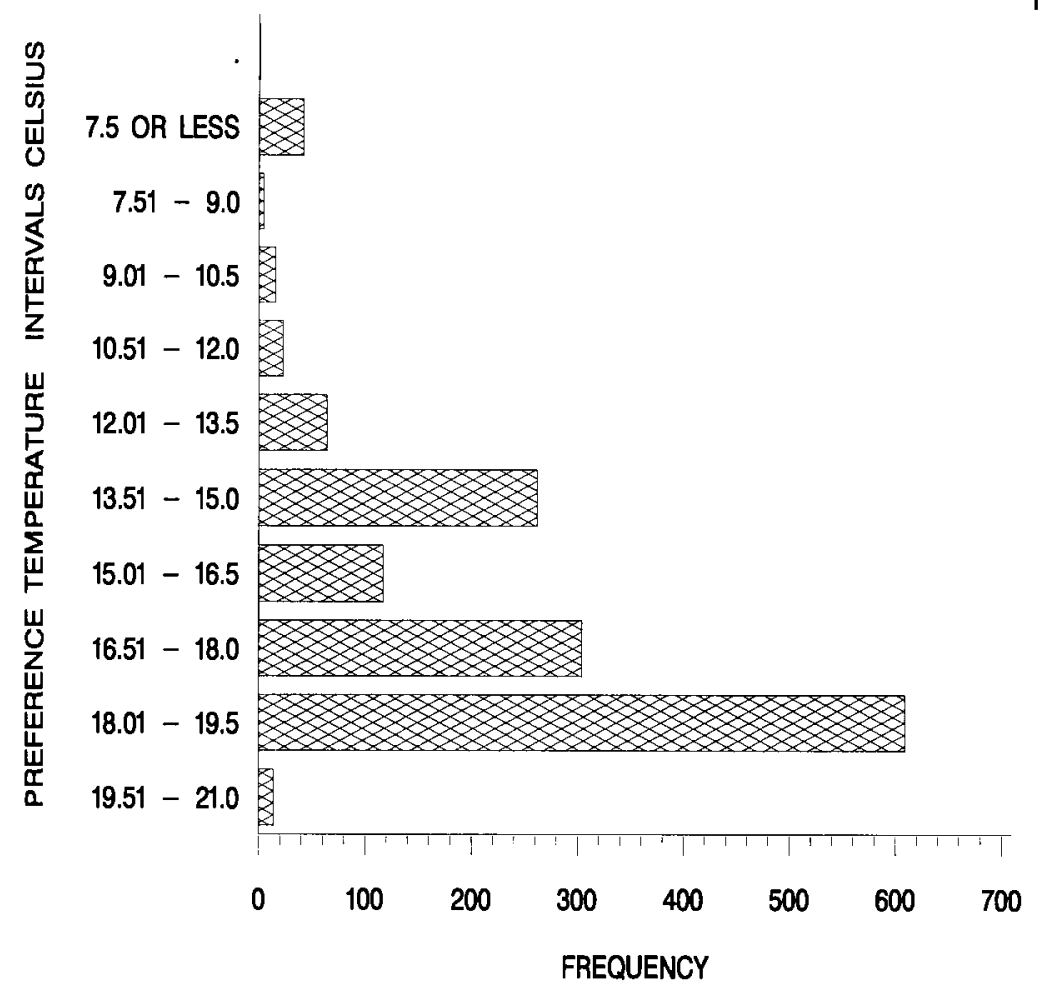

\begin{tabular}{|c|c|c|c|}
\hline FREQ. & $\begin{array}{l}\text { CUM. } \\
\text { FREQ. }\end{array}$ & PCT. & $\begin{array}{l}\text { CUM. } \\
\text { PCT. }\end{array}$ \\
\hline 1 & 1 & 0.07 & 0.07 \\
\hline 42 & 43 & 2.88 & 2.95 \\
\hline 5 & 48 & 0.34 & 3.29 \\
\hline 16 & 64 & 1.10 & 4.39 \\
\hline 23 & 87 & 1.58 & 5.97 \\
\hline 64 & 151 & 4.39 & 10.36 \\
\hline 262 & 413 & 17.98 & 28.35 \\
\hline 117 & 530 & 8.03 & 36.38 \\
\hline 304 & 834 & 20.86 & 57.24 \\
\hline 609 & 1443 & 41.80 & 99.04 \\
\hline 14 & 1457 & 0.96 & 100.0 \\
\hline
\end{tabular}

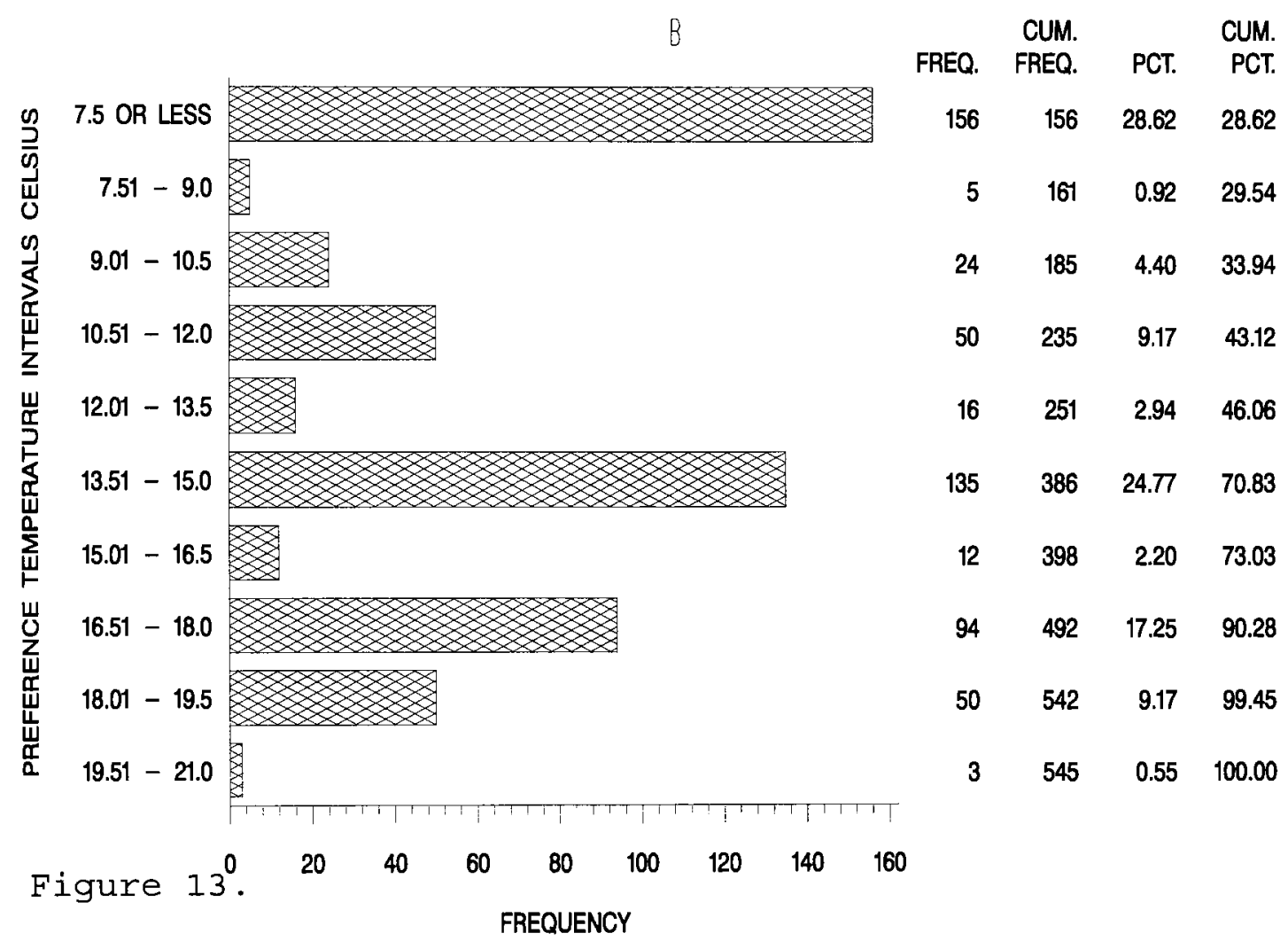


Figure 14. Frequency distribution of preference temperatures for fall chinook salmon held at $8^{\circ} \mathrm{C}$. Preference temperature observations were collected for 17 consecutive weeks from $5 / 13 / 94$ to $8 / 30 / 94$. 


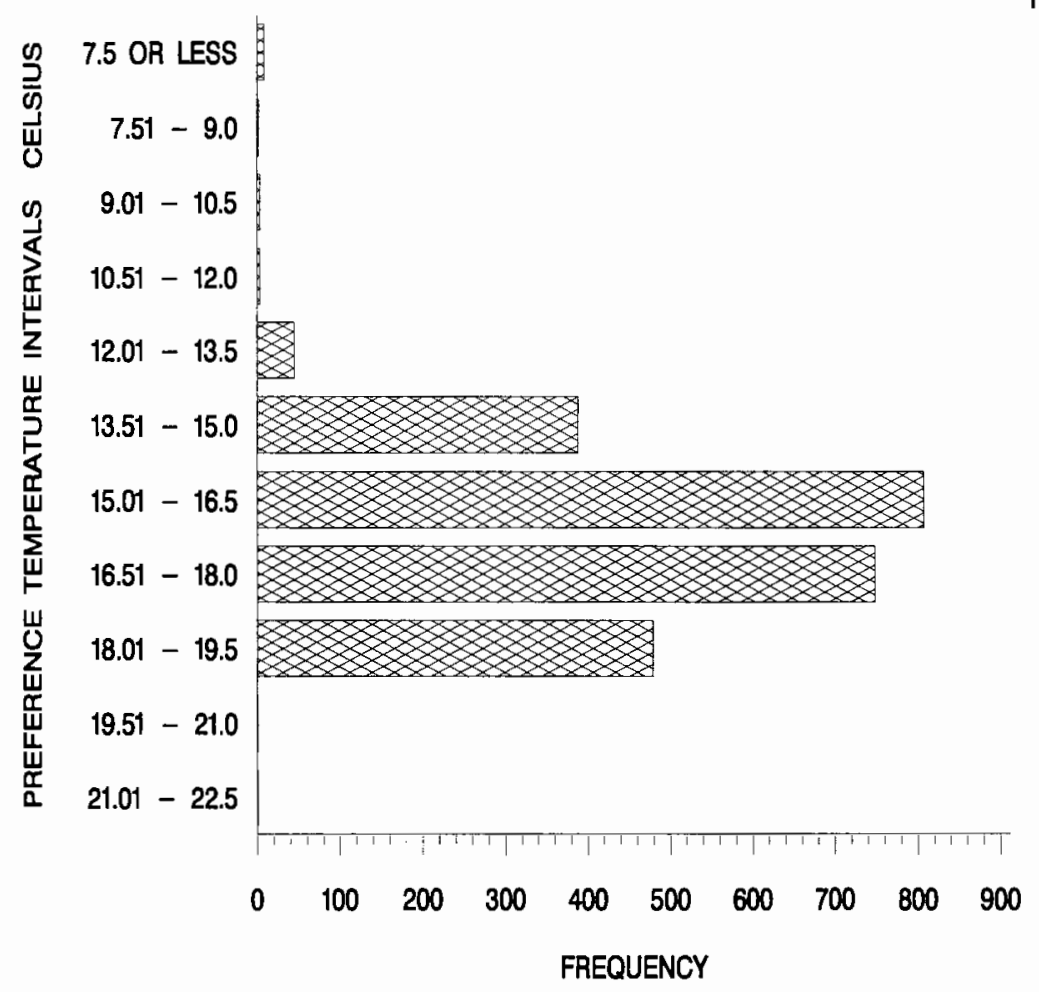

Figure 14.

$\begin{array}{rrrr} & \text { CUM. } & & \text { CUM. } \\ \text { FREQ. } & \text { FREQ. } & \text { PCT. } & \text { PCT. } \\ 9 & 9 & 0.36 & 0.36 \\ 2 & 11 & 0.08 & 0.44 \\ 4 & 15 & 0.16 & 0.60 \\ 4 & 19 & 0.16 & 0.76 \\ 45 & 64 & 1.81 & 2.57 \\ 388 & 452 & 15.59 & 18.17 \\ 807 & 1259 & 32.44 & 50.60 \\ 748 & 2007 & 30.06 & 80.67 \\ 479 & 2486 & 19.25 & 99.92 \\ 1 & 2487 & 0.04 & 99.96 \\ 1 & 2488 & 0.04 & 100.00 \\ & & & \\ & & & \end{array}$


C $(32.44 \%)$ and 16.51 to $18.0(30.06 \%)$. Smaller percentages of observations occurred in class intervals 13.51 to $15.0^{\circ}$ $\mathrm{C}(15.59 \%)$ and 18.01 to $19.5^{\circ} \mathrm{C}(19.25 \%)$. Few observations were recorded at or below $13.5^{\circ} \mathrm{C}(2.57 \%)$ or above $19.5^{\circ} \mathrm{C}$ $(0.08 \%)$

\section{Gill $\mathrm{Na}^{+}-\mathrm{K}^{+}$ATPase Curves}

Gill $\mathrm{Na}^{+}-\mathrm{K}^{+}$ATPase activity curves were plotted from weekly mean gill $\mathrm{Na}^{+}-\mathrm{K}^{+}$ATPase values on each group of fish. Spring chinook salmon held at increasing water temperatures initially had a mean $\left( \pm\right.$ SEM) gill $\mathrm{Na}^{+}-\mathrm{K}^{+}$ATPase of $5.6 \mu \mathrm{mol}$ $\mathrm{P}_{\mathrm{i}} \cdot$ [mg protein] ${ }^{-1} \cdot \mathrm{h}^{-1}$ (units) on March 4, 1994 (Figure 4). Mean gill $\mathrm{Na}^{+}-\mathrm{K}^{+}$ATPase levels increased, peaking at 12.4 ATPase units on April 12, 1994, then decreased to pre-smolt levels by June 7, 1994 .

Initial mean gill $\mathrm{Na}^{+}-\mathrm{K}^{+}$ATPase for spring chinook salmon held at $8^{\circ} \mathrm{C}$ was 7.6 ATPase units on March 9, 1994 (Figure 6). Three weeks later, on March 30, the mean gill $\mathrm{Na}^{+}-\mathrm{K}^{+}$ATPase levels rose to 13.5 ATPase units, then declined to pre-smolt levels over the next two weeks. Mean gill $\mathrm{Na}^{+}-\mathrm{K}^{+}$ ATPase levels increased again to 12 ATPase units, and continued an upward trend. By June 8, mean gill $\mathrm{Na}^{+}-\mathrm{K}^{+}$ATPase activity had risen to 19.4 ATPase units, then declined slightly the following week. Mean gill $\mathrm{Na}^{+}-\mathrm{K}^{+}$ATPase levels in spring chinook salmon held at $8^{\circ} \mathrm{C}$ had not returned to pre-smolt levels when thermal preference experiments ended 
in mid-June, 1994 .

Fall chinook salmon held on an increasing water temperature schedule showed an initial mean gill $\mathrm{Na}^{+}-\mathrm{K}^{+}$ ATPase level of 6.6 ATPase units on March 18, 1994 (Figure 9). Mean gill $\mathrm{Na}^{+}-\mathrm{K}^{+}$ATPase levels exhibited a positive trend over the 20 weeks these fish were tested. A steady 5 week increase in mean gill $\mathrm{Na}^{+}-\mathrm{K}^{+}$ATPase levels began on May 5 , 1994. Mean gill $\mathrm{Na}^{+}-\mathrm{K}^{+}$ATPase remained elevated the final two weeks this group was run.

Fall chinook salmon held at $8^{\circ} \mathrm{C}$ showed an initial mean gill $\mathrm{Na}^{+}-\mathrm{K}^{+}$ATPase level of 8.0 ATPase units on April 1, 1994 (Figure 10). Mean gill $\mathrm{Na}^{+}-\mathrm{K}^{+}$ATPase levels showed a positive trend over the next 18 weeks. Mean gill $\mathrm{Na}^{+}-\mathrm{K}^{+}$ATPase levels peaked at 14.7 ATPase units on August 4, 1994, then declined slightly over the next 3 weeks, increasing again on August $30 t h$, the last day of the experiment.

\section{Thyroxine Activity}

Mean thyroxine levels ranged from 4.6 to $12.02 \mathrm{ng} / \mathrm{ml}^{-1}$ over the course of smoltification in the spring chinook salmon held in increasing water temperatures (Figure 4). No correlation was found between mean gill $\mathrm{Na}^{+}-\mathrm{K}^{+}$ATPase and mean thyroxine levels (Table 6). Graphical representation showed that mean thyroxine levels roughly mirrored mean gill $\mathrm{Na}^{+}-\mathrm{K}^{+}$ATPase activity. A peak in mean thyroxine activity followed the gill $\mathrm{Na}^{+}-\mathrm{K}^{+}$ATPase peak in this group of $\mathrm{fish}$ 
Table 6. Adjusted coefficient of determination $\left(r^{2}\right)$, probability of significant correlation (P), and sample size (N) of correlation between mean thyroxine and mean gill $\mathrm{Na}^{+}-\mathrm{K}^{+}$ATPase levels in spring and fall chinook held at increasing water temperatures (ESCH and $\mathrm{EFCH}$, respectively) and at $8^{\circ} \mathrm{C}(\mathrm{OSCH}$ and $\mathrm{OFCH}$, respectively).

\begin{tabular}{lrrr} 
Group & $\mathrm{N}$ & \multicolumn{1}{c}{$\mathrm{r}^{2}$} & \multicolumn{1}{c}{$\mathrm{P}$} \\
\hline ESCH & 16 & 0.1784 & 0.1220 \\
OSCH & 15 & -0.0742 & 0.8592 \\
EFCH & 15 & 0.3864 & 0.0272 \\
OFCH & 15 & 0.1565 & 0.0895 \\
\hline
\end{tabular}


(Figure 4).

Spring chinook salmon held at $8^{\circ} \mathrm{C}$ had mean thyroxine levels ranging from 6.92 to $16.22 \mathrm{ng} / \mathrm{ml}^{-1}$ during smolt development (Figure 6). No correlation was found between mean thyroxine levels and mean gill $\mathrm{Na}^{+}-\mathrm{K}^{+}$ATPase (Table 6). A rise in mean thyroxine values to $15.74 \mathrm{ng} / \mathrm{ml}^{-1}$ occurred concurrently with an increase in mean gill $\mathrm{Na}^{+}-\mathrm{K}^{+}$ATPase activity $\left(13.51 \mu \mathrm{mol} \mathrm{P}_{\mathrm{i}} \cdot\right.$ [mg protein] $\left.{ }^{-1} \cdot \mathrm{h}^{-1}\right)$ beginning on March 23 (Figure 6). Mean thyroxine levels subsequently declined to $10.96 \mathrm{ng} / \mathrm{ml}^{-1}$ three weeks later, then peaked again at $14.54 \mathrm{ng} / \mathrm{ml}^{-1}$, then tended downward as mean gill $\mathrm{Na}^{+}-\mathrm{K}^{+}$ ATPase levels continued to climb.

Fall chinook salmon held at increasing water temperatures showed mean thyroxine activity ranging from 3.7 to $11.70 \mathrm{ng} / \mathrm{ml}^{-1}$ during smoltification (Figure 9). There was no correlation between mean preference temperature and mean thyroxine levels (Table 4). A positive correlation was found between mean gill $\mathrm{Na}^{+}-\mathrm{K}^{+}$ATPase and mean thyroxine levels in this group of fish (Table 6). Most notable was the rapid rise in mean thyroxine levels to $11.70 \mathrm{ng} / \mathrm{ml}^{-1}$ on May 5 , immediately preceding a progressive four week rise in mean gill $\mathrm{Na}^{+}-\mathrm{K}^{+}$ATPase levels (Figure 9).

Mean thyroxine activity in fall chinook salmon held at $8^{\circ} \mathrm{C}$ ranged from 2.2 to $18.4 \mathrm{ng} / \mathrm{ml}^{-1}$ (Figure 10 ). No correlation was found between mean gill $\mathrm{Na}^{+}-\mathrm{K}^{+}$ATPase levels 
and mean thyroxine levels (Table 6). An initial surge in mean thyroxine levels from $2.2 \mathrm{ng} / \mathrm{ml}^{-1}$ on April 22 to a peak of $18.4 \mathrm{ng} / \mathrm{ml}^{-1}$ on April 29 preceded a progressive five week rise in mean gill $\mathrm{Na}^{+}-\mathrm{K}^{+}$ATPase activity (Figure 10). Three smaller rises in mean thyroxine levels on June 17, July 15 and August 10, are apparent as smolt development progressed. Each of these small increases in mean thyroxine levels preceded increases in mean gill $\mathrm{Na}^{+}-\mathrm{K}^{+}$ATPase activity.

\section{Discussion}

This study has established that preference temperature in chinook salmon can be influenced by a variety of physiological and environmental factors. Factors such as thermal history (i.e. constant or increasing water temperature), fish size (fork length), season (time), and to a lesser extent fish development (ATPase and thyroxine activity) correlated with preference temperature, although none of these factors were correlated significantly in all four of the experimental groups.

The most dynamic thermal preference pattern was observed in fall chinook salmon that had been held at increasing water temperatures. Thermal preference dropped sharply late in smoltification in this group of $f$ ish, and was correlated most closely with mean fork lengths $\geq 105 \mathrm{~mm}$. 
This preference temperature pattern resembles the pattern described for many metamorphosing anuran amphibians (Wollmuth et al. 1987). Thermal preference studies on larval bullfrogs (Rana catesbeiana) and a montane frog (Rana cascadae) have shown that selected water temperature increased by a few degrees early in metamorphosis, peaking at about $30^{\circ} \mathrm{C}$ during middle and climax metamorphosis, then dropped precipitously to less than $20^{\circ} \mathrm{C}$ in the final stages of metamorphosis (Crawshaw et al. 1992; wollmuth et al. 1987). Although size of the animal and nutritional status are important in initiating developmental differentiation, it is water temperature that determines the rate of transformation (Clarke et al. 1981; Crawshaw et al. 1992). It appears that subyearling chinook salmon and temperate climate anuran amphibians which may reach growth and nutritional thresholds for differentiation late in the season may be able to neurologically assess water temperature stimuli before shifting energy supplies from storage to developmental differentiation (Crawshaw et al. 1992) .

Gill ATPase activity contributed significantly to the stepwise multiple correlation equation for fall chinook salmon held at increasing water temperatures as well. However, fork length alone correlated more closely with thermal preference in fall chinook salmon, perhaps an 
indication of the strong influence that size has on initiating smolt development (Adams and Thorpe 1989). Thyroxine activity correlated with ATPase activity in this group of fall chinook salmon as well, strengthening evidence for a developmental component in the fall chinook salmon thermal preference pattern.

Gill ATPase activity, which was used as a measure of smolt development in this study, correlated with preference temperature in the spring chinook salmon held at $8^{\circ} \mathrm{C}$. The correlation between preference temperature and ATPase activity may actually reflect fishes' thermal history. Preference temperature increased during smolt development by about $1^{\circ} \mathrm{C}$ over time in spring and fall chinook salmon held at $8^{\circ} \mathrm{C}$, suggesting this increased thermal preference was related to enhanced growth and smolt development. The increase in thermal preference associated with gill ATPase activity may be a response to the inhibitory effect of low holding temperature on smolt development during a time when photoperiod cues would normally be accelerating ATPase activity. That is, the fish in this study may have sought out higher water temperatures to accelerate the parr to smolt transformation.

Preference temperature correlated significantly with fork length in three of the four groups of salmon in this experiment. The relationship observed between preference 
temperature and fork length in this study is an important one. Temperature is the most important factor affecting growth because of pervasive affects on metabolic rate and therefore food requirements (Brett 1979).

Spring and fall chinook salmon at a constant $8^{\circ} \mathrm{C}$ during smolt development grew more slowly and were smaller throughout the experimental period than fish in increasing water temperatures despite large rations. Preference temperature correlated well with fork length in both experimental groups held at $8^{\circ} \mathrm{C}$. A thermal preference pattern similar to that of fall chinook salmon in increasing water temperature was observed in both groups at $8^{\circ} \mathrm{C}$; however, the rapid drop in preference temperature late in smolt development seen in fall chinook salmon in increasing water temperatures was not observed in either race of chinook salmon at $8^{\circ} \mathrm{C}$.

Ewing et al. (1979) suggest there is a critical size threshold below which chinook salmon will not smolt. Other research on chinook salmon indicates there is considerable variation in the size of chinook salmon at smoltification (Healey 1991). Critical size thresholds for smoltification may vary with water temperature and feeding opportunities, with slower growing stocks smolting later and at a smaller size than faster growing stocks (Weatherly and Gill 1995). Fall chinook salmon held at $8^{\circ} \mathrm{C}$ may not have reached 
a critical size threshold to complete smoltification and therefore did not express the entire thermal preference pattern observed in fall chinook salmon in increasing water temperatures. Spring chinook salmon at $8^{\circ} \mathrm{C}$ also failed to display the thermal preference pattern observed in fall chinook salmon in increasing water temperatures, although these fish were longer than the fall chinook salmon. Smolt development may not have reached completion in this group either due to the inhibitory effect of low water temperature.

Interestingly, spring chinook salmon held at increasing water temperatures displayed an unchanging thermal preference pattern as they underwent smoltification. Several factors may account for the observed difference in thermoregulatory behavior between spring and fall chinook salmon. The group of spring chinook salmon held in increasing water temperatures was inadvertently exposed to one week of extended photoperiod in mid-February. The low, early-season peak in gill $\mathrm{Na}^{+}-\mathrm{K}^{+}$ATPase activity observed in this group of fish is a very different activity pattern than that seen in the other three groups of fish, suggesting smolt development was accelerated by the short exposure to advanced photoperiod. Further evidence of this possibility can be extrapolated from comparison of the gill $\mathrm{Na}^{+}-\mathrm{K}^{+}$ATPase activity with thyroxine activity for this group (Figure 10). 
The peak in thyroxine levels occurred later than the gill $\mathrm{Na}^{+}-\mathrm{K}^{+}$ATPase peak, raising the possibility that the brief extended photoperiod uncoupled gill $\mathrm{Na}^{+}-\mathrm{K}^{+}$ATPase activity from endogenous thyroxine cycles (Norris 1985; Underwood 1989) .

Another explanation for the difference in behavioral thermoregulation between the two races is that the spring chinook salmon used in this study were taken from hatchery stock of mixed origin that has been artificially propagated at the Little white Salmon National Fish Hatchery for nearly 30 years (Nelson and Bodle 1990). It is possible that the thermoregulatory behavior described in this study for fall chinook salmon and by wollmuth et al. (1987) and Wollmuth et al. (1988) for larval anuran amphibians has been lost with homogeneity of the gene pool in this stock of spring chinook, or that hatchery rearing conditions and/or practices have attenuated the response. For example, it is common for salmon hatcheries to strive for production of larger parr at release by feeding fish over the winter and early spring months when feeding opportunities in the natural environment would be greatly reduced. The spring chinook salmon used in this experiment were reared on a typical hatchery feeding protocol their first year of life, and were fed twice daily to satiation at the research facility. Chinook salmon which do not reach salt water will 
revert to the parr life history stage, and resume growth in freshwater (Weatherly and Gill 1995). Studies on anuran amphibians have shown consistently that somatic growth is favored over developmental differentiation under favorable feeding conditions (Alford and Harris 1988). Somatic growth may have been favored over differentiation by spring chinook salmon in this study because of long-term, heavy feeding. Further, the possibility exists that spring chinook salmon may not show the downward shift in thermal preference seen in fall chinook until exposure to seawater.

Another alternative is that spring chinook salmon may have a thermal preference pattern distinct from that of fall chinook salmon. Differences in smolt timing, size at smoltification and genetic background between spring and fall chinook salmon may account for the variation in thermoregulatory behavior. Clarke et al. (1981) investigated the effect of water temperature, photoperiod, and salinity on growth rate of fall chinook, coho (O. kisutch), and sockeye ( 0 . nerka) salmon fry. In all three species, temperature had the greatest effect on growth rate, while photoperiod influenced growth rate and smolt development only in coho salmon. Growth rate in fall chinook salmon fry did not vary with photoperiod length at three different rearing temperatures (Clarke et al. 1981). Research on spring chinook salmon indicates this race is responsive to 
photoperiod cues (Ewing et al. 1979; Clarke et al. 1989).

Given the differential sensitivity between spring and fall chinook salmon to photoperiod and water temperature cues, it is interesting to note that thermal preference in spring chinook salmon held at $8^{\circ} \mathrm{C}$ was more closely associated with season (time), than with size (fork length) in this study. The relationships between preference temperature, season, and size are linear in spring chinook salmon, compared to the curvilinear thermal preference relationships with season (time) and with size (fork length) seen in fall chinook salmon. This observation probably reflects genetic differences in sensitivity to photoperiod and temperature cues between spring and fall chinook salmon. Fall chinook salmon emigrate during late spring and summer, when photoperiod is longest on either side of the summer solstice. Research from this and other studies suggest fall chinook salmon are more responsive to thermal than photoperiod cues from the environment (Clarke et al. 1981). Spring chinook salmon migrate in the spring, as photoperiod is lengthening, hence their pattern of smolt development over time may proceed in a more linear fashion with increasing daylength.

Variation in the rearing and migratory strategies of spring and fall chinook salmon, and the genetic components of these behaviors may also explain the different thermal 
preference patterns observed in this study. Spring chinook salmon spawn in, and immature fish rear in, cold headwater streams, while fall chinook salmon utilize higher order tributaries and the mainstem of the Columbia River for spawning and rearing. The large tributaries and mainstem Columbia River are generally much warmer than headwaters during the summer and fall months. Migration patterns of spring and fall chinook salmon also differ notably. In the Columbia River, spring chinook salmon migrate during March, April, and May, during lengthening photoperiod, when water temperatures in the river increase from near $6^{\circ}$ to $14^{\circ} \mathrm{C}$. Fall chinook salmon migrate in June, July and August, when photoperiod is long, and water temperatures are commonly between $14^{\circ}$ and $20^{\circ} \mathrm{C}$.

The effect of water temperature on physiological reaction rates of aquatic ectotherms and the low photoperiod sensitivity of fall chinook salmon emphasizes the importance of water temperature in the early life history of this race. The shift from rearing to active migration in fall chinook salmon appears to be cued primarily by water temperature and growth rate (Clarke et al. 1981). This life history strategy suggests that fall chinook salmon may utilize thermal refugia and display a greater degree of thermoregulatory behavior in the field than spring chinook salmon. Furthermore, middle to late summer water temperatures in the 
lower Columbia River commonly exceed the preference temperatures recorded for juvenile fall chinook salmon in this and other studies (Brett 1952; Brett et al. 1982), suggesting that the accelerated biological reaction rates at these elevated water temperatures may be metabolically inefficient and favor smolt differentiation. The much reduced time in freshwater of fall chinook salmon compared to spring chinook salmon may represent an evolutionary adaptation driven primarily by seasonal differences in water temperatures between the ecological niches of the two races. The significant drop in preference temperature described for smolted fall chinook salmon may reflect the high metabolic costs of osmoregulation in a freshwater environment while physiologically adapted to the marine environment. A decreased preference temperature would slow metabolic rate, reducing energy costs while freshwater emigration was completed.

During smoltification, glycogen and lipid levels are depleted due to decreased synthesis and increased breakdown of these energy stores (Sheridan et al. 1983, 1985a; Sheridan 1986). Salmon smolts store high levels of longchain fatty acids and low amounts of linoleic acid, a lipid storage pattern consistent with other marine fishes (Hoar 1988). Developmental changes in the degree of fatty acid saturation, the cholesterol/phospholipid ratios, and the 
fluidity of fats enhance cellular permeability and temperature compensation in the marine environment (Hoar 1988). Metabolic shifts in the utilization of glycogen and/or lipid energy stores and the associated endocrine responses may signal thermoregulatory changes in the central nervous system of vertebrate ectotherms.

Marine research indicates that all species of salmon migrate seasonally in response to ocean temperatures (Welch et al. 1995). Salmon in the ocean migrate south into warmer waters during spring and summer, and north into cooler water ( $<7^{\circ} \mathrm{C}$ ) again in the fall and winter (Welch et al. 1995). It seems likely that the shift to cooler water temperatures described in this study for smolting fall chinook salmon represents a broader life history strategy than just readjustment of biological reaction rates after differentiation. In addition to physiological adaptation to the marine environment, neurological development and subsequent genetic expression of innate daily and seasonal thermal preference cycles of the differentiated oceanic life history stage may be considered the final outcome of successful smoltification. This hypothesis is supported by the difference in thermoregulatory patterns between spring and fall chinook salmon observed in this study. Spring chinook salmon would enter oceanic waters in the late spring and summer, when innate seasonal preference temperature 
would favor warmer waters. Fall chinook salmon, entering the ocean during the summer and fall months after rearing in freshwater reservoirs and the estuary, would express the fall/winter thermal preference pattern described by welch et al. (1995). Finally, the lower preference temperature described for smolted fall chinook salmon may be considered preadaptive, augmenting movement of smolted fall chinook salmon from the freshwater river system into the cooler marine environment.

In this study, weekly mean preference temperatures ranged from 15.2 to $17.8^{\circ} \mathrm{C}$ in fall chinook salmon before dropping to $10.8^{\circ} \mathrm{C}$ near the end of smolt development. The frequency distribution shows that these fish were selecting temperatures $\leq 7.5^{\circ} \mathrm{C}$ for a significant part of the time. The large decrease in preference temperature towards the end of smoltification suggests this thermoregulatory behavior serves the same function as that hypothesized for anuran amphibian metamorphosis - - to slow the rate of physiological reactions, including the activity of thyroid hormones on tissues, and reestablish efficient metabolic rates for somatic growth in the new form and environment after large scale developmental differentiation (Regard 1978; Norris 1985; Crawshaw et al. 1992).

The biological significance of temperature-driven developmental transformations in aquatic ectotherms is 
developmental plasticity in responding to heterogeneous annual temperature cycles. The developmental plasticity described here for chinook salmon, and by Crawshaw et al. (1992) for anuran amphibians, has been shaped by natural selection and represents an important ectothermic life history strategy for survival and ultimately reproductive success.

\section{Implications}

The results presented in this study strongly suggest that water temperature can alter the rate of smolt development as well as migratory behavior in chinook salmon. These findings are particularly relevant to fall chinook salmon in the Columbia River. This race of chinook salmon may be particularly vulnerable to alterations in river flow, lotic habitat and water temperature because of their ecology. Summer emigration of fall chinook salmon occurs at a time when release of water from reservoirs is greatly reduced, compounding the problem of flow and migrant travel time seen during spring chinook salmon migration (Breggren and Filardo 1993). In addition, fall chinook salmon migrate at a time when water temperatures in the Columbia River are at their highest.

Reduction in the natural flow rate of the Columbia River during the summer months and the large reservoirs formed by hydroelectric projects may present serious 
ecological obstacles for outmigrating fall chinook salmon. For example, Ledgerwood et al. (1991) found that emigrating fall chinook salmon use nearshore areas for feeding and migration more extensively than spring chinook salmon outmigrants. This critical nearshore habitat would be unavailable to young fall chinook salmon if water temperature rose above tolerance limits of the fish. It seems reasonable to assume, given adequate food availability, that higher water temperatures in the Columbia River would accelerate growth and smolt development in juvenile fall chinook salmon. More rapid growth and smolt development of fall chinook salmon would increase the necessity for adequate summer water flows through reservoirs to move smolting fish seaward. Elevated water temperature could become deleterious to juvenile salmon. In this study, fall chinook salmon stopped feeding when holding temperature rose above $20^{\circ} \mathrm{C}$ (S. Sauter, personal observation) -- a temperature where increased induction of thermal stress proteins has also been noted in salmon (M. Hargis, personal communication). Water temperature is a pervasive ecological factor, influencing everything from the basic chemicals of life to complex behavior with genetic underpinnings. Simple assumptions about the effects of altered water temperature in the Columbia River on the early life history stages of chinook salmon are not enough. 
Hydroelectric development, logging, chemical pollution, and other man-caused habitat alterations, as well as natural climatic cycles have resulted in massive ecological perturbations in the Columbia River drainage (Trefethen 1972, Nehlsen et at. 1991; Thorpe 1994; Reid et al. 1995). Basic research on anadromous salmonids is crucial to understanding the adaptive constraints of these animals. Effective fisheries policy and management of endangered anadromous salmonid stocks in the Columbia River Basin requires an understanding of the impact of environmental temperatures on the ecology of remaining wild populations and on survival of hatchery-reared stock. 


\section{Literature Cited}

Adams, C.E. and Thorpe, J.E. 1989. Photoperiod and temperature effects on early development and reproductive investment in At lantic salmon ( Salmo salar L.). Aquaculture 79:403-409.

Alford, R.A. and Harris, R.N. 1988. Effects of larval growth history on anuran metamorphosis. American Naturalist $131: 91-106$.

Berggren, T.J. and Filardo, M.J., 1993. An analysis of variables influencing the migration of juvenile salmonids in the Columbia River Basin. North American Journal of Fisheries Management. 13:48 - 63.

Brett, J.R. 1952. Temperature tolerance in young Pacific salmon, genus Oncorhynchus. Journal of the Fisheries Research Board of Canada. 26:2363 - 2394 .

Brett, J.R. 1971. Energetic responses of salmon to temperature: a study of some thermal relations in the physiology and freshwater ecology of sockeye salmon (oncorhynchus nerka). American Zoologist. 11: 99 - 113.

Brett, J.R. 1979. Environmental factors and growth, p. 599 675. In: W.S. Hoar, D.J. Randall, and J.R. Brett (eds.). Fish physiology. Volume 8. Bioenergetics and growth. Academic Press, New York.

Brett, J.R., Clarke, W.C., and Shelbourn J.E. 1982. Experiments on the thermal requirements for growth and food conversion efficiency of juvenile chinook salmon Oncorhynchus tshawytscha. Canadian Technical Report on Fish and Aquatic Science 1127:29.

Clarke, W.C., Shelbourn, J.E., and Brett, J.R. 1981. Effect of artificial photoperiod cycles, temperature, and salinity on growth and smolting in underyearling coho (Oncorhynchus kisutch), chinook (O. tshawytscha), and sockeye (O. nerka) salmon. Aquaculture 22:105-116.

Clarke, W.C., Shelbourn, J.E., Ogasawara, T., and Hirano, T. 1989. Effect of initial daylength on growth, seawater adaptability and plasma growth hormone levels in underyearling coho, chinook, and chum salmon. Aquaculture 82:51-62. 
Crawshaw, L.I. 1979. Responses to rapid temperature change in vertebrate ectotherms. American Zoologist. 19:225 237 .

Crawshaw, L.I., 1980. Temperature regulation in vertebrates. Annual Review of Physiology. 42:473 - 491.

Crawshaw, L.I., Moffitt, B.P., Lemons, D.E., and Downey, J.A. 1981. The evolutionary development of vertebrate thermoregulation. American Scientist 69:543-550.

Crawshaw, L.I., wollmuth, L.P., O'Connor, C.S., Rausch, R.N. and Simpson, L. 1990. Body temperature regulation in Vertebrates: Comparative aspects and neuronal elements. In: Thermoregulation and Biochemistry, pp. $209-220$, Schonbaum, E. and Lomax, P. (Eds)., Pergamon Press, Inc. New York.

Crawshaw, L.I., Rausch, R.N., wollmuth, L.P., and Bauer, E.J. 1992. Seasonal Rhythms of Development and Temperature Selection in Larval Bullfrogs, Rana catesbeiana Shaw. Physiological Zoology 65(2):346-359.

Dickhoff, W.W., Folmar, L.C., and Gorbman, A. 1978. Changes in plasma thyroxine during smoltification of coho salmon, Oncorhynchus kisutch. General and Comparative Endocrinology. 36:229-232.

Dickhoff, W.W., Folmar, L.C., Mighell, J.L., and Mahnken, C.V.W. 1982. Plasma thyroid hormones during smoltification, with special reference to metabolic and developmental processes. American Fisheries Society Symposium. 1:197-210.

Dickhoff, W.W. and Darling, D.S. 1983. Evolution of thyroid function and it's control in lower vertebrates. American Zoologist. 23:697-707.

Ebel, W.J., C. D. Becker, J.W. Mullan, H.L. Raymond. 1989. The Columbia River-toward a holistic understanding, $p$. 205 - 219. In D.P. Dodge (ed.) Proceedings of the International Large River Symposium. Canadian Special Publication of Fish and Aquatic Science. 106.

Ewing, R.D., Johnson, S.L., Pribble, H.J., and Lichatowich, J.A. 1979. Temperature and photoperiod effects on gill $\left(\mathrm{Na}^{+}-\mathrm{K}^{+}\right.$) ATPase activity in chinook salmon (Oncorhynchus tshawytscha) Journal Fisheries Research Board of Canada. 36:1347-1353. 
Folmar, L.C. and Dickhoff, W.W., 1980. The parr - smolt transformation (smoltification) and seawater adaption in salmonids. A review of selected literature. Aquaculture 21:1 -37.

Fry, F.E.J. 1947. Effects of the environment on animal activity. Univ. Toronto Studies in Biology series 55. Publ. Ont. Fish Research Laboratory. 68: 1 - 62 .

Healy, M.C. 1991. Life History of chinook salmon (Oncorhynchus tshawytscha), p. 311-393. In: C. Groot and L. Margolis (eds.). Pacific salmon life histories. UBC Press, Vancouver. 564 p.

Hickman, C.P. Jr., Roberts, L.S., and Hickman F.M. (Eds). 1984. The Fishes, The Amphibians, The Reptiles. In: Integrated Principles of Zoology. pp. 518-598. Times Mirror/Mosby College Publishing, st. Louis, Missouri.

Hoar, W.S. 1976. Smolt Transformation: evolution, behaviour, and physiology. Journal of the Fisheries Research Board of Canada. 33:1233-1252.

Hoar, W.S. 1988. The physiology of smolting salmonids, p. 275-343. In: W.S. Hoar and D.J. Randall (eds.). Fish Physiology. Volume 11B. Gills:anatomy, gas transfer, and acid-base regulation. Academic Press, New York.

Johnson, C.E. and Eales, J.G. 1970. Influence of body size on silvering of Atlantic salmon (Salmo salar) at parr smolt transformation. Journal of Fisheries Research Board of Canada. 27:983 - 987.

Konstantinov, A.A., Zdanovich, V.V., and Tikhomirov, D.G. 1989. The effect of temperature fluctuations on metabolic rate and energetics of juvenile fish. Voprosy Ikhtiologii 29:1019-1027.

Kwain, W. and R.W. McCauley. 1978. Effects of age and overhead illumination on temperatures preferred by underyearling rainbow trout, salmo gairdneri, in a vertical temperature gradient. Journal of the Fisheries Research Board of Canada. 35: 1430 - 1433.

Ledgerwood, R.D., Thrower, F.P. and Dawley, E.M., 1990. Diel sampling of migratory juvenile salmonids in the Columbia River estuary. Fishery Bulletin 89:69 - 78 .

Love, R.M., 1980. The chemical biology of fishes, Vol. 2 . Academic Press, New York. 
Magnuson, J.J., Crowder, L.B., P.A. Medvick. 1979. Temperature as an ecological resource. American Zoologist. 19: 331 - 343 .

Mathur, D. and Silver, C.A. 1980. Statistical Problems in Studies of Temperature Preference of Fishes. Canadian Journal of Fish and Aquatic Science. 37:733-737.

Mathur, D., Schutsky, R.M., Purdy, E.J., and Silver, C.A. 1981. Similarities in Acute Temperature Preferences of Freshwater Fishes. Transactions of the American Fisheries Society. 110:1-13.

MaCauley, R.W. and Huggins, N.W. 1979. Ontogenetic and NonThermal Seasonal Effects on Thermal Preferenda of Fish. American Zoologist. 19: 267 - 271.

Minkoff, E.C. 1984. Evolutionary Biology. Addison - Wesley Publishing Company, Inc., Reading, Massachusetts. p. 266 .

Morin, P.P. and Dodson, J.J., 1989. Thyroid activity concomitant with olfactory learning and heart rate changes in Atlantic salmon, Salmo salar, during smoltification. Canadian Journal of Fisheries and Aquatic Science. 46:131 - 136.

Nehlsen, W., J.E. Williams, J.A. Lichatowich. 1991. Pacific Salmon at the Crossroads: stocks at Risk from California, Oregon, Idaho, and Washington. Fisheries $16: 4-21$.

Nelson, W.R. and Bodle, J. 1990. Ninety Years of Salmon Culture at Little white Salmon National Fish Hatchery. U.S. Fish and Wildlife Service, Biological Report $90(17) .22 \mathrm{p}$.

Norris, D.O. 1985. Vertebrate Endocrinology. Lea \& Febiger Publishing, Philadelphia, Penn. p.162-201.

Piper, R.G., McElwain, I.B., Orme, L.E., McCraren, J.P., Fowler, L.G., and Leonard, J.R. 1986. Fish Hatchery Management. United States Department of the Interior. Fish and Wildlife Service. Washington D.C. p. 71-75.

Premdas, F.H. and Eales, J.G. 1976. The influence of TSH and $\mathrm{ACTH}$ on purine and pteridine deposition in the skin of rainbow trout (Salmo gairdneri). Canadian Journal of Zoology. 54:576-581. 
Raymond, H.L. 1979. Effects of dams and impoundments on migrations ofjuvenile chinook salmon and steelhead from the Snake River, 1966 to 1975. Transactions of the American Fisheries Society. 108:505 - 529.

Regard, E., 1978. Cytophysiology of the amphibian thyroid through larval development and metamorphosis. International Review of Cytology. 52:81 - 118.

Reid, S.D., Dockray, J.J., Linton, T.K, McDonald, D.G., and Wood, C.M. 1995. Effects of a summer temperature regime representative of a global warming scenario on growth and protein synthesis in hardwater- and softwateracclimated juvenile rainbow trout. Journal of Thermal Biology. 20:448-458.

Reynolds, W.W. 1977c. Fever and antipyresis in the bluegill sunfish, Lepomis macrochirus. Comparative Biochemistry and Physiology. 57C:165 - 167 .

Reynolds, W.W. 1977. Temperature as a proximate factor in orientation behavior. Journal of the Fisheries Research Board of Canada. 34:734 - 739.

Reynolds, W.W., Casterlin, M.E. and Covert, J.B., 1977a. Febrile responses of aquatic ectotherms to bacterial pyrogens. American Zoologist. 17:903.

Reynolds, W.W. and Covert, J.B., 1977. Behavioral fever in aquatic ectothermic vertebrates. In: K.E. Cooper, P. Lomax, and E. Schonbaum (Eds.), Drugs, biogenic amines and body temperature, pp. 108 - 110. Karger, Basel.

Reynolds, W.W. and Casterlin, M.E. 1979. Behavioral thermoregulation and the "final preferendum" paradigm. American Zoologist. 19:221-224.

Rodgers, J.D., Ewing, R.D., and Hall, J.D. 1987. Physiological changes during seaward migration of wild juvenile coho salmon (Oncorhynchus kisutch). Canadian Journal of Fisheries and Aquatic Science. 44:452 - 457.

Rounsefell, G.A. 1958. Anadromy in North American Salmonidae. U.S. Fish and Wildlife Service Bulletin 58: $171-185$.

Schrock, R.M., Beeman, J.W., Rondorf, D.W. and Haner, P.V., 1994. A microassay for gill sodium, potassium-activated ATPase in juvenile Pacific salmonids. Transactions of 
the American Fisheries Society. 123:223 -229.

Sheridan, M.A., Allen, W.V., and Kerstetter, T.H. 1983. Seasonal variations in the lipid composition of the steelhead trout, Salmo gairdneri Richardson, associated with the parr - smolt transformation. Journal of Fish Biology. 23:125 - 134.

Sheridan, M.A., Allen, W.V., and Kerstetter, T.H. 1985a. Changes in the fatty acid composition of steelhead trout, salmo gairdneri Richardson, associated with patt - smolt transformation. Comparative Biochemistry and Physiology B. 80B:671 - 676 .

Sheridan, M.A. 1986. Effects of thyroxine, cortisol, growth hormone, and prolactin on lipid metabolism of coho salmon, oncorhynchus kisutch, during smoltification. General and Comparative Endocrinology. 64:220 - 238 .

Thorpe, J.E. 1981. Migration in Salmonids, with special reference to juvenile movements in freshwater. E.L. Brannon and E.O. Salo (Eds.) In: Salmon and Trout Migratory Behavior Symposium pp. 86 - 97.

Thorpe, J.E. 1987. Downstream migration of young salmon: recent findings, with special reference to Atlantic salmon, salmo salar L. In: Proceedings of the salmonid migration and distribution symposium. Brannon, E. and Jonsson, B. (Eds). No. 793 .

Thorpe, J.E. 1994. Salmonid Flexibility: Responses to Environmental Extremes. Transactions of the American Fisheries Society. 123:606-612.

Trefethen, P. 1972. Man's Impact on the Columbia River. In: Oglesby, R.T., Carlson, C.A., and McCann, J.A. (eds.) River Ecology and Man. Proceedings of an International Symposium on River Ecology and the Impact of Man, University of Massachusetts, Amherst, Massachusetts. Academic Press, New York. p. 77-98.

Underwood, H. 1989. The pineal and melatonin: Regulators of circadian function in lower vertebrates. Experientia $45: 914-922$.

Weatherly, A.H. and Gill, H.S. 1995. Growth. p. 103-158. In: C. Groot, L. Margolis, and W.C. Clarke (eds.) Physiological Ecology of Pacific Salmon. UBC Press, Vancouver. $510 \mathrm{p}$. 
Welch, D.W., Chigirinshy, A.I., and Ishida, Y. 1995. Upper thermal limits on the oceanic distribution of Pacific salmon (Oncorhynchus spp.) in the spring. Canadian Journal of Fisheries and Aquatic Science. 52:489 - 503 .

Wollmuth, L.P., Crawshaw, L.I., Forbes, R.B. and Grahn, D.A., 1987. Temperature selection during development in a montane anuran species, Rana cascadae. Physiological Zoology. $60(4): 472-480$.

Wollmuth, L.P. and Crawshaw, L.I., 1988. The effect of development and season on temperature selection in bullfrog tadpoles. Physiological Zoology. 61(5):461 469 .

Youngson, A.F. and Simpson, T.H., 1984. Changes in serum thyroxine levels during smolting in captive and wild Atlantic salmon, Salmo salar L. Journal of Fish Biology. $24: 29-39$.

Zaugg, W.W. and McLain, L.R. 1970. Adenosine triphosphatase activity in gills of salmonids: Seasonal variations and salt water influence in coho salmon, (Oncorhynchus kisutch). Comparative Biochemistry and Physiology. $35: 587-596$.

Zaugg, W.W. and McLain, L.R. 1972. Changes in gill adenosinetriphosphatase activity associated with parr smolt transformation on steelhead trout, coho, and spring chinook salmon. Journal of the Fisheries Research Board of Canada. 29: 167 - 171.

Zaugg, W.W. and Wagner, H.H., 1973. Gill ATPase activity related to parr-smolt transformation and migration in steelhead trout (Salmo gairdneri): Influence of photoperiod and temperature. Comparative Biochemistry and Physiology. 45B:955 -965.

Zaugg, W.W. 1981. Relationships between smolt indices and migration in controlled and natural environments. In: E.L. Brannon and E.O. Salo (eds.). Salmon and trout migratory behavior symposium. University of Washington, seattle. p. 173-183.

Zaugg, W.W. 1982. A simplified preparation for adenosine triphosphatase determination in gill tissue. Canadian Journal of Fisheries and Aquatic Science. 39:215 - 217. 
